\title{
Trophic structure in the Gulf of Lions marine ecosystem (north-western Mediterranean Sea) and fishing impacts
}

\author{
D. Bănaru ${ }^{a, b, *}$, C. Mellon-Duval ${ }^{a}$, D. Roos ${ }^{a}$, J.-L. Bigot ${ }^{a}$, A. Souplet ${ }^{a}$, A. Jadaud ${ }^{a}$, P. Beaubrun ${ }^{\text {, }}$ \\ J.-M. Fromentin ${ }^{a}$
}

\author{
a IFREMER, Centre Halieutique Méditerranéen et Tropical, Laboratoire Ressources Halieutiques, B.P. 171, \\ Avenue Jean Monnet, 34203 Sète, France \\ b Aix-Marseille Université, Mediterranean Institute of Oceanography (M.I.O), UMR 7294, UR 235, Campus de \\ Luminy, Case 901, 13288 Marseille Cedex 09, France \\ ${ }^{c}$ Ecole Pratique de Hautes Etudes, University of Montpellier, France \\ *: Corresponding author : Daniela Bănaru, Tel: + 33 (0)4 91829120 ; Fax: + 33 (0)4 91826548 ; \\ email address : Daniela.Banaru@univ-amu.fr
}

\begin{abstract}
:
The Gulf of Lions ecosystem was described using the Ecopath mass-balance model to characterise its structure and functioning and to examine the effects of the multispecific fisheries operating in this area. The model is composed of 40 compartments, including 1 group of seabirds, 2 groups of cetaceans, 18 groups of fish, 12 groups of invertebrates, 5 groups of primary producers, detritus and discards. Input data were based on several recurrent scientific surveys, two alternative datasets for fishing data, stock assessment outputs, stomach content analyses and published information. Results showed that the functional groups were organised into five trophic levels with the highest one represented by dolphins, anglerfish, Atlantic bluefin tuna, European hake and European conger. European pilchard and European anchovy dominated in terms of fish biomass and catch. Other fish with high biomass such as Atlantic mackerel and blue whiting were highly important in the food web. Seabirds, dolphins and cuttlefish-squids represented keystone species. Important coupled pelagic-demersal-benthic interactions were described. The 7 different fisheries analysed were operating at mean trophic levels situated between 2.6 for small artisanal boats, and 4.1 for purse seines $(>24 \mathrm{~m})$ targeting large pelagic fish, indicating an intensively exploited ecosystem. Large trawlers $(24-40 \mathrm{~m})$ had the highest impact on most of the groups considered; while purse seines $(12-24 \mathrm{~m})$ targeting small pelagic fish had the lowest impact. Preliminary results highlighted the importance of data sources for further ecosystem and fisheries analyses and management scenarios.
\end{abstract}

\section{Highlights}

We characterize the structure and the functioning of the food web in the Gulf of Lion. European pilchard and European anchovy represented key link groups and high landings. We showed coupling between compartments and top-down control by demersal predators. Indices showed that the Gulf of Lion's ecosystem was highly exploited by fisheries. Large trawls had the most negative impact and small purse seines had the lowest one.

Keywords: Gulf of Lions ; Ecopath with Ecosim ; Food web ; Fishing impacts 


\section{Introduction}

The Gulf of Lions is an important feeding area for fish, birds and mammals, for both resident and migratory species. It represents a highly productive system because of the Rhone River inputs, coastal upwelling activity, bottom morphology and water circulation (Lefevre et al., 1997; Agostini and Bakun 2002; Petrenko et al., 2005; Hu et al., 2009). In this area many species of commercial interest have been intensively exploited on the continental shelf and upper slope for decades by the French and Spanish fleets using multispecific artisanal gear such as trawlers, purse seines, gillnets and other gear (Farrugio et al., 1993; Lleonart and Maynou, 2003; Sacchi, 2008). Throughout the Mediterranean Sea, marine resources have been exploited since ancient times (Margalef, 1985), although in the last decades the development of fishing technologies and the increasing demand for marine resources have generated a stronger and more amplified pressure on marine resources. Current analyses suggest that most demersal and pelagic stocks are fully exploited or overexploited (Aldebert and Recasens, 1996; Sardà, 1998; Papaconstantinou and Farrugio, 2000; Bas et al., 2003; FAO, 2009).

Fishing is known to be one of the major human disturbances in coastal marine ecosystems (Jennings and Kaiser, 1998; Jackson et al., 2001). It has various kinds of direct and indirect impact, in addition to those induced by oceanographic features and other anthropogenic and natural disturbances (Hall, 1999; Christensen et al., 2003). According to Food and Agriculture Organisation (FAO 1995, 2002) "the achievement of real marine ecosystem-based management of fisheries implies the regulation of the use of the living resources based on the understanding of the structure and dynamics of the ecosystem of which the resource is a part". This requires an improvement in our understanding of the structure and functioning of exploited ecosystems and of the changes induced in them by human and environmental factors.

In the north-western Mediterranean Sea coupled physical and biogeochemical models were made (Baklouti et al., 2006). In these models the highest trophic level was represented by mesozooplankton (Eisenhauer et al., 2009).

This work is the first ecosystem modelling approach in the Gulf of Lions ecosystem, taking into account the entire food web from primary producers to top predators, and covering a large area from the coast up to $2500 \mathrm{~m}$. The objective was to analyse the structure and the functioning of the food web and to estimate the relative impact of the different fishing gear. To do so, we used the Ecopath with Ecosim (EwE) software that has been widely used in many places over the world to quantitatively describe marine and aquatic ecosystems and to 
assess fishing impact (Pauly et al., 2000; Christensen and Walters, 2004). Ecosystem modelling has been proposed as a management tool for marine fisheries (Plagányi, 2007) and also in Mediterranean Sea (Cochrane and De Young, 2008), where EwE models were previously made in different areas (Libralato et al., 2002; Pinnegar and Polunin, 2004; Coll et al., 2006, 2007; Tsagarakis et al., 2010; Coll and Libralato, 2011).

\section{Materials and methods}

\subsection{Study area}

The Ecopath model represents an average annual situation over the last decade (2000 - 2009) of the Gulf of Lions ecosystem covering a total area of $20400 \mathrm{~km}^{2}$ and with a bathymetry between 0 and $2500 \mathrm{~m}$. The Gulf of Lions is located in the north-western Mediterranean Sea $\left(42^{\circ} 26.3^{\prime} \mathrm{N}, 3^{\circ} 9.9^{\prime} \mathrm{E} ; 43^{\circ} 12.6^{\prime} \mathrm{N}, 5^{\circ} 27.5^{\prime} \mathrm{E}\right)$ (Fig. 1). The continental slope constitutes a long open boundary to the southeast of the Gulf. Along this boundary, the main mesoscale circulation feature is a strong geostrophic current, the Northern Current, which generally flows along the continental slope of the Gulf of Lions (Millot, 1999). The dominant forcing drivers in the area are the strong north-western (tramontane) and northern (mistral) winds which induce strong coastal upwelling activity (Millot, 1999, Agostini and Bakun, 2002), the western Mediterranean mesoscale circulation, and the fresh water input from the Rhone River (Petrenko et al., 2005). These drivers generate important primary and secondary production and the Rhone River is an important source of dissolved and particulate organic matter in this system (Lefevre et al., 1997; Gaudy et al., 2003; Harmelin et al., 2008). The Gulf of Lions shows a decreasing trend in nutrient concentration and production from east to west and from the continental shelf to deeper waters. The substrate is characterised by muddy and sandy bottoms. The area presents a high diversity of organisms and many aspects of their ecology and biology have been investigated over the past decades (Beaubrun, 1995; Labrune et al., 2007; Hermand et al., 2008; Mellon-Duval et al., 2009).

\subsection{The Ecopath model}

The Ecopath and Ecosim (EwE) modelling approach version 6 (Christensen and Walters, 2004; Christensen et al., 2008; Link, 2009; www.ecopath.org) was used to ensure the energy balance of the model of the Gulf of Lions' marine system. Ecopath has been widely used for constructing, parametrisation and analysis of food web models of aquatic and terrestrial 
ecosystems. It led to generalisations on the structure and functioning of many marine ecosystems and has been used in fisheries assessments.

EwE divides the production $(\mathrm{P})$ of each component or functional group (i) of the ecosystem into: (1) predation mortality $\left(\mathrm{M} 2_{\mathrm{ij}}\right)$ caused by the biomass of the predators $\left(\mathrm{B}_{\mathrm{j}}\right),(2)$ exports from the system both from fishing activity $\left(\mathrm{Y}_{\mathrm{i}}\right)$ and (3) other exports $\left(\mathrm{E}_{\mathrm{i}}\right)$, (4) biomass accumulation in the ecosystem $\left(\mathrm{BA}_{\mathrm{i}}\right)$ and $(5)$ baseline mortality or other mortality $\left(1-\mathrm{EE}_{\mathrm{i}}\right)$, where EE is the ecotrophic efficiency of the group within the system, or the proportion of the production of (i) that is exported out of the ecosystem (i.e. by fishing activity) and consumed by predators within it.

$\mathrm{P}_{\mathrm{i}}=\Sigma \mathrm{B}_{\mathrm{j}} * \mathrm{M} 2_{\mathrm{ij}}+\mathrm{Y}_{\mathrm{i}}+\mathrm{E}_{\mathrm{i}}+\mathrm{BA}_{\mathrm{i}}+\mathrm{P}_{\mathrm{i}} *\left(1-\mathrm{EE}_{\mathrm{i}}\right)$

This equation can be re-expressed as:

$\mathrm{B} *(\mathrm{P} / \mathrm{B})_{\mathrm{i}}=\Sigma \mathrm{B}_{\mathrm{j}} *(\mathrm{Q} / \mathrm{B})_{\mathrm{j}} * \mathrm{DC}_{\mathrm{ij}}+\mathrm{Y}_{\mathrm{i}}+\mathrm{E}_{\mathrm{i}}+\mathrm{BA}_{\mathrm{i}}+\mathrm{B}_{\mathrm{i}} *(\mathrm{P} / \mathrm{B})_{\mathrm{i}} *\left(1-\mathrm{EE}_{\mathrm{i}}\right)$

where $(\mathrm{P} / \mathrm{B})_{\mathrm{i}}$ indicates the production of (i) per unit of biomass and is equivalent to total mortality, or Z, under steady-state conditions (Allen, 1971); (Q/B) is the consumption of (i) per unit of biomass; and $\mathrm{DC}_{\mathrm{ij}}$ indicates the proportion of (i) that is in the diet of predator (j) in terms of volume or weight units. EwE parameterizes the model by describing a system of linear equations for all the functional groups of the model, where for each equation three of the basic parameters: $\mathrm{B}_{\mathrm{i}},(\mathrm{P} / \mathrm{B})_{\mathrm{i}},(\mathrm{Q} / \mathrm{B})_{\mathrm{i}}$ or $\mathrm{EE}_{\mathrm{i}}$ have to be known for each group (i). The energy balance of each trophic group (i) is given by the basic equation:

consumption $(i)=\operatorname{production}(i)+\operatorname{respiration}(i)+$ unassimilated food (i)

When the system equations are solved they provide a snapshot of the trophic flow within the system. Units of the model are expressed in $\mathrm{t} \mathrm{km}^{-2} \mathrm{y}^{-1}$ wet weight organic matter for flows

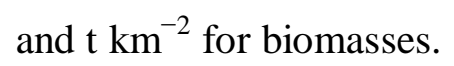

Input parameters of the Gulf of Lions model were : B (biomass), P/B (production/biomass ratio), Q/B (consumtion/biomass ratio), EE (ecotrophic efficiency) for some groups, U/Q (assimilation rate estimated from the ratio unassimilated/consumed food), catch and discards, diet composition and net migration rate (estimated as "imports" in the diet).

The Automatic Mass Balance Procedure (Kavanagh et al., 2004) was used after having modified some data with higher uncertainty in terms of biomass. These changes concerned some invertebrates (benthic primary producers, zooplankton, cuttlefish-squids and echinoderms) and fish species (other planctonophagous fish, blue whiting, Atlantic horse mackerel and European conger). For the majority of these groups initial biomass was assessed by the swept area method applied to experimental trawl survey data. In these cases the alternative input of EE taken from other studies in similar areas in the literature was used to estimate the biomass of species/groups from the food demands of the upper levels and 
fisheries. Anyway this is a weak point of the model because such parameter is contextdependent, functional group-dependent, but also dependent of the structure of the model (Christensen et al., 2005; Plagányi, 2007), the effect of this parameter is top-down (Steele, 2009) and it is a parameter that can not be estimated from the field.

The model was considered balanced when: (1) realistic estimates of the missing parameters were obtained $(\mathrm{EE}<1),(2)$ values of production/consumption ratios $(\mathrm{P} / \mathrm{Q}$, or gross efficiency of food conversion) for functional groups were between 0.10 and 0.35 with the exception of fast growing groups with higher values and top predators with lower values, (3) values of respiration/biomass ratios $(\mathrm{R} / \mathrm{B})$ were consistent with the group's activities with high values for small organisms and top predators, (4) values of respiration/food assimilation ratios (R/A) were $<1$ and values for top predators were higher, (5) values of net efficiency of food conversion were $<1$ for all the functional groups (Christensen et al., 2005).

The "pedigree" of input data was recorded, identifying whether it was taken from a model of a similar system, or based on a rough or precise estimate from local data. These values were then used to assess model quality (Pauly et al., 2000; Christensen and Walters, 2004; Christensen et al., 2005).

\subsection{Functional groups and data sources}

The model is composed of 40 functional groups, including 5 groups of primary producers, detritus and discards, 12 groups of invertebrates, 18 groups of fish, 1 group of seabirds and 2 groups of cetaceans (Table 1, Appendix 1). It includes more than $99 \%$ of the exploited fish and invertebrate species in the Gulf of Lions.

All functional groups of the model were described in term of species composition and percentages of biomass in Table 1. Twelve fish species, the most important in term of landings in this area, were considered as individual functional groups in the model (Table 1). Other 29 fish species that are important for the fisheries and the food web were grouped. Cluster analysis using Ward method and mean distance between classes, based on the similarity of their diet produced 5 groups of fish (Appendix 2). The main preys of fish from each of these groups were: mesozooplankton, plants, fish, benthic crustaceans and other benthic invertebrates. Initially we had also other group of fish feeding on macroozooplankton, including blue whiting and Mediterranean horse mackerel which was finally separated as they have different biomasses and ecological role in the system. The group of fish feeding on fish, initially composed of pelagic and bentho-demersal species, was also separated for the same reasons into two groups. The pelagic fish group feeding on fish is composed of chub mackerel 
and swordfish, while the bentho-demersal group includes raies, small-spotted catshark, East Atlantic red gurnard and two flat fish species.

Initial inputs and the diet composition matrix of the model are shown in Tables 2 and 3.

Definition of the groups was based on similarities in their ecological and biological features (feeding, habitat) and on the importance of the species in terms of fisheries.

Two size groups of pelagic primary producers were considered in the model: pico-nano and microphytoplankton, as in the pelagic compartment predation is known to be mostly sizedependent (Shin and Cury, 2004). Pelagic invertebrates were grouped according to size, as consumption is also often conditioned by size and sampling in this compartment is also generally focused on size. Gelatinous organisms were considered separately from the other macrozooplankton organisms because they have a different trophic role (Javidpour et al., 2009).

Some authors have chosen not to represent in their models the area between 0 and 10 meters or 50 meters because of the lack of knowledge and data on benthic primary producers and invertebrates (Coll et al., 2006, 2007; Tsagarakis et al., 2010). A preliminary analysis of the spatial distribution of the main commercial fish species in the Gulf of Lions showed that $60 \%$ of their biomass is located in the 0 - 50 meter area (Banaru, pers. comm., estimated from "International bottom trawl survey in the Mediterranean" (MEDITS) and "Pelagique Méditerranée" (PELMED) indices of biomass by species and by bathymetric strata). Therefore, this area represents a very important feeding ground for most of the functional groups and we decided to include it in our study.

Benthic primary producers such as Posidonia oceanica, benthic macrophytes and microphyto benthos were included in the model. These groups represent important food sources in the area situated between 0 and $30 \mathrm{~m}$.

Benthic and demersal invertebrates were grouped, based on published prey types of fish. The main commercial fish species were considered separately because better information about their different input parameters was available. This separation will further help in studying the impact of fisheries on the functioning the Gulf of Lions ecosystem. In addition to these 29 key commercial species, a hierarchical classification of the fish species according to their prey was performed to detect the other fish species/groups that have to be included in the model. Seabirds, dolphins and whales were also considered as functional groups in the model. An annual average model was described, in which biomass, diet and species composition in different seasons were averaged according to available data and time series (Appendix 1). When available, published and unpublished sources concerning the Gulf of Lions were used 
to generate input parameters, but it was necessary to draw some parameters from the literature more widely in some cases.

Biomass $\left(\mathrm{t} \mathrm{km}^{-2}\right)$ was estimated using satellite and literature data for the phytoplankton groups. For pelagic and benthic vertebrates and invertebrates, we used information from scientific surveys, especially recurrent aerial, acoustic and bottom trawl surveys that have been carried out by the French Research Institute for Exploration of the Sea (IFREMER) in the Gulf of Lions for several years/decades, as well as published information and results from the General Fisheries Commission for the Mediterranean (GFCM) stock assessment working groups for exploited fish populations (Appendix 1). Biomass of fish and invertebrates was estimated for each bathymetric stratum (0-2500 m). Mean biomass for the Gulf of Lions was estimated taking in account the weight of each stratum in the total surface area (Bertrand et al., 1998). Limited information was available for some groups, such as the benthic primary producers, and input parameters $(\mathrm{P} / \mathrm{B}$ and $\mathrm{Q} / \mathrm{B})$ and the alternative EwE input were used to estimate the biomass of these groups from the food demands of the upper levels. Estimated biomass of birds and mammals was based on the number of resident and migratory species and individuals from the studied area (Appendix 1).

Detritus biomass was estimated from primary production using an empirical equation (Pauly et al., 1993). The microbial food web was not directly considered in the model, but it was indirectly considered within the box of detritus compartment (Calbet et al., 2002). We chose this parameterization because (1) inputs for the microbial food-web are scarce and difficult to estimate, (2) their flows could overshadow other trophic flows in the system (Christensen et al., 2005), and (3) previous models built for the Mediterranean Sea did not directly include the dynamic of the microbial food-web (see Pinnegar, 2000; Coll et al., 2006, 2007; Tsagarakis et al., 2010).

Production/biomass ratios $(\mathrm{P} / \mathrm{B})\left(\mathrm{y}^{-1}\right)$ and consumption/biomass ratios $(\mathrm{Q} / \mathrm{B})\left(\mathrm{y}^{-1}\right)$ were taken from the literature or obtained from the application of empirical equations (Palomares and Pauly, 1998; Christensen et al., 2005) using length and weight data (data sources in Appendix 1). The $\mathrm{P} / \mathrm{B}$ values of the phytoplankton and zooplankton groups were estimated using in-situ data from published results (Appendix 1). Assimilation rates were compiled from published information. Input parameters (P/B, Q/B and sometimes $\mathrm{EE})$ for the invertebrates were taken from models built in similar areas (data sources in Appendix 1). For fish, birds and mammals these parameters were estimated using empirical equations (Nilsson and Nilsson, 1976; Innes et al., 1987; Trites et al., 1997; Palomares and Pauly, 1998; Christensen et al., 2005). In the absence of information, steady state conditions were assumed with biomass accumulation $(B A)=0$. Migratory patterns of some species (Atlantic bluefin tuna, some mammals, birds and 
fish) were taken into account by "modelling" a proportion of the diet of these groups as "imports" to the system. For example Atlantic bluefin tuna living 6 months by year in the studied area was feeding $50 \%$ in the system and other $50 \%$ of his diet was coming from "imports".

Diets were estimated using published information on stomach content analyses for fish, birds and mammals and stable isotope analyses for most of the invertebrate groups. Diets of invertebrates, birds and mammals originated from the studied area. Data on fish diets concerned the Gulf of Lions (33\%), the Mediterranean Sea (80\%), and the north-eastern Atlantic (20\%) (Appendix 1). The weight of species' diet in the functional group's diet was proportional to their percentage of biomass in the group. The input parameters $(\mathrm{P} / \mathrm{B}, \mathrm{Q} / \mathrm{B}$ and $\mathrm{U} / \mathrm{Q}$ ) of the mixed groups were estimated by weighting the inputs by the relative biomass of each species following default procedures (Christensen et al., 2005; Coll et al., 2006, 2007). Seven multi-species artisanal fleets operating in this area were included in the model: trawls $(12-24 \mathrm{~m})$ and purse seine $(<12 \mathrm{~m})$, trawls $(24-40 \mathrm{~m})$, purse seine $(12-24 \mathrm{~m})$, purse seine $(>24 \mathrm{~m})$, gillnet $(<12 \mathrm{~m}<3$ nautical miles), gillnet $(<12 \mathrm{~m}, 12-18 \mathrm{~m}>3$ nautical miles), other small gear $(<12 \mathrm{~m},<3$ nautical miles) (Demaneche et al., 2009). Trawls are operating in both bottom and mid-waters; large purse seines $>24 \mathrm{~m}$ are targeting large pelagic fish while smaller purse seines $12-24 \mathrm{~m}$ are targeting small pelagic fish. Input concerning landings $\left(\mathrm{t} \mathrm{km}^{-2} \mathrm{y}^{-1}\right)$ was mostly based on two data sources compiled by IFREMER: (i) the R3 report that compiled observed landings of all fishing gears operating in the area in 2007-2008 and (ii) the IFREMER database (2002-2009) called "Harmonie" which is based on auction sales reports of French catches operated in the Gulf of Lions (Demaneche et al., 2009; Fisheries Information System, IFREMER). These data sources were completed by data on Spanish catches made in the Gulf of Lions for the 30 most important species/groups (B. Guijarro from IEO, pers. comm.). Landings registered in the R3 report for the Atlantic bluefin tuna (mostly juveniles) and European hake were likely underestimated (Fromentin, Jadaud and Mellon-Duval, pers. comm.). These values were corrected from the survey of the French purse seiners fleet operating in the Mediterranean Sea for the Atlantic bluefin tuna (Fromentin, pers. comm, mean values of landings 2001-2006) and stock assessment commissions (GFCM, mean values of landings 1998-2008) for the European hake. Discard data $\left(\mathrm{t} \mathrm{km}^{-2} \mathrm{y}^{-1}\right)$ concerned only some pelagic fish species (sardine and horse mackerel) and were based on a preliminary IFREMER report (IFREMER, 2009). In the Gulf of Lions very small individuals of all species are usually sold on markets and other discards are probably low (Farrugio, pers. comm.). Anyway this study does not include illegal, unreported and unregulated (IUU) fishing estimations such data were not available. 
Two different Ecopath models were balanced using either the R3 or the Harmonie data (both completed by Spanish data) to compare the sensitivity of EwE parameters to different sources of landings.

\subsection{Model analysis}

Ecological indices were used to analyse fishing impacts based on trophic flow analysis, thermodynamic concepts, information theory and trophodynamic indicators (Christensen and Walters, 2004; Christensen et al., 2005; Cury et al., 2005).

Total trophic flows within the ecosystem in terms of consumption, production, respiration, exports and imports and flow to detritus $\left(\mathrm{t} \mathrm{km}^{-2} \mathrm{y}^{-1}\right)$ were quantified. The sum of all these flows, the Total System Throughput (TST), can be seen as an indirect indicator of the size of the ecosystem (Christensen and Pauly, 1993).

The Trophic Levels (TL) of the functional groups were also calculated. The TL was first defined as an integer identifying the position of organisms within food webs (Lindeman, 1942) and it was later modified to make it fractional (Odum and Heald, 1975). Following an established convention, a TL of 1 is attributed to primary producers and detritus, a TL of 2 to herbivores and detritivores, a TL of 3 to first order carnivores and a TL of 4 to second order carnivores. Thus, the TL can be formulated as follows: $\mathrm{TL}_{\mathrm{j}}=1+\Sigma \mathrm{DC}_{\mathrm{ij}} * \mathrm{TL}_{\mathrm{i}}$, where $\mathrm{j}$ is the predator of prey $\mathrm{i}, \mathrm{DC}_{\mathrm{ji}}$ is the fraction of prey $\mathrm{i}$ in the diet of predator $\mathrm{j}$ and $\mathrm{TL}_{\mathrm{i}}$ is the trophic level of prey i. Trophic flows and TL can be represented in terms of a flow diagram by functional group.

From trophic flows and TLs, the Transfer Efficiency (TE) can be calculated, which summarizes all the inefficiencies of the food web (due to respiration, excretion, egestion and other natural mortality) present at each step of the trophic chain. Linderman spine is produced for aggregation of flows with the same number of steps (trophic links) (Lindeman, 1942).

Detritus and primary producers were represented separated and linked. The TE is obtained by calculating the ratio between the production of a given TL and the preceding TL (Lalli and Parsons, 1993; Pauly and Christensen, 1995). Flows, TLs and TE were visualized in the form of a Lindeman Spine (Lindeman, 1942; Ulanowicz, 1986; Wulff et al., 1989; Libralato et al., 2002).

The Mixed Trophic Impact (MTI) analysis (Ulanowicz and Puccia, 1990), quantifies direct and indirect trophic interactions among functional groups. It provides a quantification of the positive or negative impact that a hypothetical increase in the biomass of a group would produce on the other groups in the ecosystem, including the fishery. 
The net MTI $\left(\mathrm{m}_{\mathrm{ij}}\right)$ was also used to estimate the overall impact $\varepsilon_{\mathrm{i}}$ on functional group $\mathrm{j}$,

$$
\varepsilon_{i}=\sqrt{\sum_{j=1}^{n} m_{i j}^{2}}
$$

where in $\mathrm{m}_{\mathrm{ij}}$ the impact on the group itself is not considered. By plotting the overall impact (or relative total impact) $\varepsilon_{\mathrm{i}}$ versus the keystoneness $\left(\mathrm{KS}_{\mathrm{i}}\right)$, we can identify keystone groups (groups that play an important role in the food-web with relatively low biomass) and the dominant groups (groups that play an important role and have a relative large biomass) in the ecosystem, as proposed by Libralato et al. (2006).

$\mathrm{KS}_{\mathrm{i}}=\log \left[\varepsilon_{\mathrm{i}}\left(1-\mathrm{p}_{\mathrm{i}}\right)\right]$, where $\mathrm{p}_{\mathrm{i}}$ is the relative biomass of the group, excluding detritus biomass. The indicated keystone and dominant groups are system specific and may differ if the ecosystem is disturbed (Libralato et al., 2006; Coll et al., 2009; Coll and Libralato, 2011), thus this indicator is sensitive to changes in the food-web.

The exploitation rate $(\mathrm{F} / \mathrm{Z})$ is the ratio of the fishery-induced mortality $(\mathrm{F})$ relative to total mortality $(Z)$ and was used to assess the exploitation status of each functional group. The Primary Production Required (PPR) to sustain the fishery, the average Trophic Level of the Catch (TLc), partitioning of mortalities, the Gross Efficiency of the fishery (GEf=catch/primary production) and the relative consumption of total production, were analysed to place the fisheries within the ecosystem context (Cury et al., 2005). The PPR from the primary production and detritus (flows from $\mathrm{TL}=1$ ), typically measured as $\mathrm{t} \mathrm{km}^{-2} \mathrm{y}^{-1}$, is obtained by back-calculating the flows, expressed in primary production and detritus equivalents, for all pathways from the caught species down to the primary producers and detritus (Pauly and Christensen, 1995). It is formulated as: PPR $=1 / 9 * \Sigma\left[\mathrm{Y}_{\mathrm{i}} *(1 / \mathrm{TE})^{\mathrm{TLi}-1}\right]$, where $Y_{i}$ is the catch of a given group (i), TE is the mean transfer efficiency, $T L_{i}$ is the trophic level of group (i) and factor 1/9 is taken as the average conversion coefficient from wet weight to $\mathrm{g} \mathrm{C}$. This index can be expressed per unit of catch relative to the primary production and detritus of the ecosystem (\%PPR). The $\mathrm{TL}_{\mathrm{c}}$ reflects the overall strategy of a fishery and is calculated by weighting the proportions of each type of organism from the catch and its TL (Pauly et al., 1998).

Odum's ecological indicators related to the ecosystem development theory (Margalef, 1968; Odum, 1969; Christensen, 1995) were also analysed. These indicators included: (a) various coefficients of flows and biomasses (total primary production/ total respiration, total production / total biomass and total biomass / total system throughputs); (b) the Finn's cycling index (which describes the fraction of the throughput that is recycled) and predatory cycling index; (c) the System Omnivory Index (SOI, which measures the distribution of the trophic interactions amoung trophic levels); and (d) the Ascendency, which is related to the average 
mutual information in a system scaled by the TST (Finn, 1976; Ulanowicz, 1986; Christensen et al., 2005). The average mutual information describes the uncertainty about where a unit of energy will flow next if we know its location (Ulanowicz and Norden, 1990).

Several models were previously built in the Mediterranean (Catalan, Adriatic and Aegean Seas) (Coll et al., 2006; Coll et al., 2007; Tsagarakis et al., 2010) and Atlantic (Cantabrian Sea) (Sánchez and Olaso, 2004). Even if similitudes exist between these models and the Gulf of Lions' model, the comparison was not possible because they cover different bathymetric areas, have differences in the model structure, the definition of some groups and parameters.

\section{Results}

\subsection{Output parameters}

Resulting output parameters of the model are shown in Table 4. Excluding detritus, $21 \%$ of the biomass was allocated to the phytoplankton groups, $11 \%$ to zooplankton, $10 \%$ to benthic primary producers, $26 \%$ to demersal and benthic invertebrates groups, $16 \%$ to small pelagic fish and $15 \%$ to other fish groups. The biomass of birds and mammals represented less than $1 \%$ in the system. The biomass was almost equally distributed between pelagic and benthodemersal compartments.

EE of the phytoplankton groups, as well as detritus and discards, were rather low and flows to detritus from these groups were high. Fish presented generally high EE values, except for Atlantic mackerel, Mediterranean horse mackerel, fish (feeding on fish) (Table 4). For some species or groups ecotrophic efficiencies (EE) were initially higher than 1 (i.e. gelatinous zooplankton, cuttlefish-squid, octopus, other planktonophagous fish, blue whiting, Atlantic horse mackerel, European conger and fish feeding on benthic crustaceans). In this case EE values come from the literature from other model in close areas.

Phytoplankton groups and worms showed the highest flows to detritus, followed by zooplankton groups, European pilchard and benthic crustaceans (Table 4).

Production/consumption ratios (P/Q) and net food conversion efficiencies were within the expected range (Christensen and Walters, 2004). These values were very low (or null) for marine mammals and birds, around 0.1 to 0.4 for most of the fish and large invertebrates while exceeding 0.45 for zooplankton (Table 4). Omnivory index was highest for juvenile Atlantic bluefin tuna and seabirds and lowest for European anchovy and other planktonophagous fish (Table 4). 


\subsection{Trophic levels and trophic flows}

Functional groups were organised into five trophic levels (Fig. 2). The trophic level of the groups ranged from 1 for primary producers up to 4.83 for dolphins. Invertebrates had trophic levels between 2.05 for microzooplankton and 3.88 for cuttlefish and squid, while the trophic levels of fish were around 3 for small pelagic fish species and higher for predator species such as anglerfish (4.45), European conger (4.16), juvenile Atlantic bluefin tuna and European hake (4.14) (Table 4).

There is high coupling through consumption between the pelagic, the demersal and the benthic compartments (Fig. 3). From this perspective, phyto and zooplankton are consumed by demersal and benthic invertebrates $\left(88 \mathrm{t} \mathrm{km}^{-2} \mathrm{y}^{-1}\right)$, which are consumed by demersal invertebrates and fish $\left(2.5 \mathrm{t} \mathrm{km}^{-2} \mathrm{y}^{-1}\right)$. Small pelagic fish are consumed by demersal and benthic predator fish $\left(3.2 \mathrm{t} \mathrm{km}^{-2} \mathrm{y}^{-1}\right)$ and small benthic fish are consumed by demersal fish $(0.6$ $\left.\mathrm{t} \mathrm{km}^{-2} \mathrm{y}^{-1}\right)$. Demersal predators thus play an important top-down control role in the food web, while the highest flows in term of biomass are due to bottom-up control in relation to the phytoplankton productivity.

The main flows $\left(\mathrm{t} \mathrm{km}^{-2} \mathrm{y}^{-1}\right)$ between trophic levels are schematically represented through the Lindeman flow diagram, where primary producers and detritus were separated to clarify the representation (Fig. 4). High flows to the detritus originated from the primary producers and TL 2. Different export values by catches were obtained according to data sources, i.e. R3 report and auction sales database, and were lower in the second case. Catch flows are highest at the TL $3\left(1.140 \mathrm{t} \mathrm{km}^{-2} \mathrm{y}^{-1}\right)$. The highest predation flows are within TL 1, 2 and 3, while flows in the upper TLs were very low. The average transfer efficiency $(\mathrm{TE}=19 \%)$ and the fraction of the total flows (that is either exported or transferred to other trophic levels through consumption) were high. Values of TE for flows between the $2^{\text {rd }}$ and $3^{\text {rd }}$ were also high and these values decreased progressively between the $2^{\text {rd }}-3^{\text {rd }}$ and the $4^{\text {th }}-5^{\text {th }}$ trophic levels.

\subsection{Consumption}

The most consumed groups in the food web were phytoplankton (53\%), zooplankton (21\%), detritus (12\%) and worms (9\%) (Fig. 5a). The consumption of biomass of all the other groups (including fish) represented less than 5\%. Among fish, the most consumed in the food web were the European pilchard (32\%), the group of other planctonophagous fish (19\%), the blue whiting (16\%), the European anchovy (15\%), the Atlantic mackerel (7\%), and the group of 
fish (feeding on benthic crustaceans) (5\%) (Fig. 5b). The consumption of all the other fish species represented less than $4 \%$ (Table 4 ).

The biomass produced by the exploited fish species was mainly consumed by fish (77\%) or exploited by fisheries (18\%). The consumption of fish by cephalopods (5\%) and other groups thus remained secondary.

\subsection{Mortality}

For most of the invertebrates and fish, especially worms, gastropods, cuttlefish and squids, benthic crustaceans, other planktonophagous fish, blue whiting, poor cod, fish feeding on benthic crustaceans and fish feeding on polychaetes, mortality was mainly due to predation. However, fishing was the main cause of mortality for some species, such as octopus, the group of fish feeding on plants, Atlantic bluefin tuna, European hake, Atlantic horse mackerel, anglerfish, European conger and gilthead seabream (Table 4).

Interestingly, for the European pilchard and European anchovy which include the highest landings in this area, the mortality was firstly due to natural causes $\left(\mathrm{M}_{0}\right)$, followed by predation and to a lesser extent by fishing. Among the most important consumers of the European pilchard were the European hake (37\%), cuttlefish-squid (35\%) and Atlantic blufin tuna (13\%). For the European anchovy the main consumers were Atlantic bluefin tuna (32\%), Atlantic mackerel (19\%) and European hake (12\%).

\subsection{Summary statistics}

Results from the ecological model in terms of aggregated summary statistics, network flows and information indices are shown in (Table 5). The total consumption and the flow to detritus dominated the Total System Throughput (TST t km ${ }^{-2} \mathrm{y}^{-1}$ ) and would represent $36.9 \%$ and $37.1 \%$ of the total flows, respectively. Indices related to Odum (1969) theory and the maturity of the system like total primary production/total biomass, connectance index, Finn's cycling index, omnivory index, ascendency and overhead showed a rather low developmental stage of the Gulf of Lions system (Table 5). Applying EwE on the two sources of landings data modified the total catches (2.131-1.274), the mean trophic level of catches (3.24-3.35), the gross efficiency $(0.002-0.001)$ and the primary production required to sustain the fisheries reported to the total primary production $(13.58-10.28)$.

\subsection{Mixing trophic impact}


Interactions within the ecosystem, analyzed using the Mixed Trophic Impact (MTI) routine, are shown in Fig. 6. These analyses describe increases or decreases in the biomass of a group that are to be expected if hypothetical changes in the biomass of another group occur. Direct impact resulting from trophic interactions can be underlined but also indirect impact due to prey availability and niche overlapping as well as to cascade effects. For example, European pilchard had a direct positive effect on their predators (such as cuttlefish-squid and hake) and a direct negative impact on their main prey (mesozooplankton). It had also an indirect negative impact on their competitors such as European anchovy and other planktonophagous fish. Through a cascade effect European pilchard negatively impacted the Atlantic mackerel and Mediterranean horse mackerel which prey on macrozooplankton and which was a competitor of the European pilchard for the mesozooplankton. Main beneficial predators were Atlantic mackerel and fish (feeding on benthic crustaceans).

Numerous functional groups in the model were impacted by groups at the base of the food web such as detritus, phytoplankton, zooplankton, worms and benthic crustaceans. European pilchard, European anchovy, and blue whiting also showed a strong impact on numerous functional groups of higher and lower TLs.

\subsection{Relative total impact and keystone index}

Sea birds, dolphins and cuttlefish-squids had the highest keystone index and very low biomass and were considered as keystone species. Fish such as Atlantic mackerel, fish feeding on benthic crustaceans, European pilchard and blue whiting, as well as some invertebrates (mesozooplankton, benthic crustaceans, echinoderms and bivalves - gastropods) had a very important role in the food web (Fig. 7). These groups had high biomass and were considered as dominant species/groups in the ecosystem. Forage groups, such as small pelagic fish, had high impact on many other groups of higher and lower trophic level in the Gulf of Lions.

\subsection{Fisheries and their impact on the functional groups}

European pilchard and European anchovy represented the main species caught and landed in the Gulf of Lions, representing 39\% and 11\% respectively (Fig. 8). Other fish species such as: Atlantic mackerel, fish feeding on benthic crustaceans, European hake, poor cod, Atlantic bluefin tuna and fish feeding on polychaetes, as well as some invertebrates (bivalvesgastropods and octopuses) showed high values in landings (Fig. 8; Appendix 3). 
The detail of landings by gear and by species from the R3 report is presented in Appendix 3 . Data on landings from auction sales are indicated for comparison in Appendix 4, but only in $\mathrm{R}$ repport the detailed values by species were available. The highest landing were made by large trawls (24-40 m) targeting mainly European pilchard and lowest ones by purse seine (> $24 \mathrm{~m})$ and gillnets $(<12 \mathrm{~m}, 12-18 \mathrm{~m},>3 \mathrm{~nm})$ targeting Atlantic bluefin tuna. Total landings in $\mathrm{R} 3$ report were $67 \%$ higher than in the auction sales database. Spanish catches represented $3.1 \%$ of the total R3 catches.

Fisheries were operating at mean trophic levels situated between 2.6 for other small gears, 3.2 to 3.8 for gillnets, 3.3 to 3.4 for trawls, 3.0 for small purse seine (12-24 m) and 4.1 for large purse seine $(24-40 \mathrm{~m})$.

Large trawls (24-40 m) had the highest landing rates and the most strongly negative impact on the majority of the groups as it is a multispecific gear, while small purse seine (12-24 $\mathrm{m}$ ) had low landing rates and the lowest impact as it targeted mainly the European pilchard (Fig. 9). In general, negatively impacted species were targeted species, while main prey (phyto and zooplankton, benthic crustaceans, other planctonophagous fish, blue whiting, fish feeding on benthic crustaceans) and competitors (gelatinous organisms) were generally positively impacted by cascade effects.

\section{Discussion}

The present paper describe the structure and the functioning of the Gulf of Lions's marine system and estimate the relative impact of the different fishing gear operating in this area. This is the first ecosystem model, including high trophic levels, conceived for this area. Similar Ecopath models were constructed in different areas in the Mediterranean sea: Catalan, Adriatic and Aegean seas (Coll et al., 2006, 2007; Tsagarakis et al., 2010). However it is rather difficult to compare these models as they were not always constructed on the same areas, for the same periods, with the same compartments and parameters. This model includes coastal area (0-50 m) with higher biomasses and goes up to deep waters $(2500 \mathrm{~m})$ with lower biomasses that the rest of the continental shelf and slope that was generally considered in the other models in the Méditerranean sea (Coll et al., 2006, 2007; Tsagarakis et al., 2010). Only the Cantabrian Sea' Ecopath model considered a similar large area (0-2000 m) (Sánchez and Olaso, 2004).

The Ecopath model of the Gulf of Lions has more photoplankton and zooplankton groups that the other models and this may affect the trophic level. However TLs in this model were in accordance with previous results for the Mediterranean and Cantabrian Seas (Stergiou and Karpouzi, 2002; Sánchez and Olaso, 2004; Coll et al., 2006, 2007; Tsagarakis et al., 2010). 
Most of the species and groups of species showed similar trophic levels between the golf of Lions and the Catalan and Adriatic Sea. There were some differences for the horse mackerels, mackerels and dolphins which showed lower values than in our study. More differences appeared with the results from the Aegean Sea where sardine and anchovy had higher trophic levels that in the golfof Lions, while horse mackerels, seabirds and dolphins showed lower trophic levels.

Coupling between the pelagic and demersal-benthic compartments was also noticed in other systems (Coll et al., 2006, 2007; Tsagarakis et al., 2010).

The highest predation flows were within TL 1, 2 and 3, while flows in the upper TLs were almost insignificant, similarly to other systems (Coll et al., 2006, 2007; Tsagarakis et al., 2010).

The average transfer efficiency was higher than in other marine systems (Coll et al., 2006, 2007; Tsagarakis et al., 2010), probably because for some groups EE was fixed to high values. Other explanations could be that low trophic level production or biomass is underestimated, or that this is real and this high TE\% is produced by large impact of removing production of the system due to fishing. Values of TE for flows through TL 2 and TL 3 were high, both suggesting good coupling between zooplanktivores and detritivores and their predators (Baird et al., 1991).

Other authors highlighted the importance of small pelagic fish species, particularly European pilchard and European anchovy as forage species within the Mediterranean foodwebs (Coll et al., 2006, 2007; Tsagarakis et al., 2010). These species represent key link groups in term of consumption and flows between pelagic primary producers and consumers from both the pelagic and the demersal compartments.

Gelatinous organisms seemed to be less important in the Gulf of Lions than in the Catalan, Adriatic and Aegean seas (Coll et al., 2006, 2007; Tsagarakis et al., 2010) because their biomass was probably underestimated and thus their importance may be underestimated. Pauly et al. (2009) also reported these problems in jellyfish parametrization.

Mortality values were in agreement with the range of values from stock assessment (Lleonart, 1990; Jadaud, pers. comm.; Roos, pers comm.), where most of the groups showed high predation mortality.

Fishing is an important pressure component in the Gulf of Lions food-web as it is responsible for a high rate of "consumption" of the fish compartment, similarly to the case in other Mediterranean ecosystems (Coll et al., 2006, 2007). Results related to fisheries like mean trophic level of the catch, gross efficiency, primary production required to sustain fishery/ total primary production and total catch were different in the two models using the two 
different fisheries datbeses and highlights the importance of these data for an eventual modelling support to the management of these ressources.

The mean trophic level of the catches was rather low, similarly to other models applied in the Mediterranean sea (Coll et al., 2006, 2007; Tsagarakis et al., 2010), but it was higher than in the Black sea (Banaru et al., 2010b) and lower than in the Cantabrian Sea (Sánchez and Olaso, 2004).

Atlantic mackerel had in the Gulf of Lions the highest role as a dominant group, just like in the Cantabrian sea system (Sánchez and Olaso, 2004). Sea birds and dolphins were keystone species like in other Mediterranean ecosystems (Coll et al., 2007). Small pelagic fish, had high impact on many other groups in the Gulf of Lions, like in other marine ecosystems (Coll et al., 2006, 2007), highlighting the importance of these groups as forage species in the ecosystem and possible wasp-waist predator-prey interactions (Cury et al., 2000).

\subsection{Improvements and limits of the data sources}

The pedigree index score of 0.67 implied a moderate quality of the data sources (Morissette, 2007), similar to other studies for the Mediterranean and Cantabrian seas (Sánchez and Olaso, 2004; Coll et al., 2006, 2007; Tsagarakis et al., 2010). However, in order to develop future Ecosim and Ecospace scenarios, based on Ecopath, some input data need to be reviewed or improved.

Phytoplankton biomass was estimated using satellite data on surface chlorophyll and a model estimating the euphotic depth. Values obtained were similar to those of previously published data. We might also compare them with results from a coupled physical and biochemical model in the Gulf of Lion - Symphonie Eco3M (Diaz and Campbell, pers. data), in order to see whether results are similar.

Zooplankton data were obtained from published in situ sampling campaigns (1998-1999). One may wonder whether the sampled period is representative or not for the entire modelled period, acknowledging that zooplankton presents large annual variations in terms of biomass, production and species composition. Results for these parameters might also be compared with the same coupled physical and biochemical model in the gulf of Lion - Symphonie Eco3M (Diaz and Campbell, pers. data).

At the same time, the Ecopath model may provide data on the consumption of phyto- and zooplankton by the organisms from the upper trophic levels. Future end-to-end models might be constructed by forcing/coupling Ecopath with Ecosim and Ecospace (high trophic level 
models) with the coupled physical and biochemical models (low trophic level models) existing for this area.

For the benthic primary producers more studies concerning the area covered in the Gulf of Lions need to be undertaken. Available data on benthic invertebrates in terms of biomass by taxonomic and trophic group concerned mainly the coastal area $(0-100 \mathrm{~m})$, but data for between 100 and 2500m were rather poor. Data on diet, and only for the coastal area (0 $100 \mathrm{~m})$, were deduced from stable isotope analyses performed on some species and then extrapolated to taxonomic groups. Further data regarding species composition, spatial distribution, biomass and diet are necessary for all benthic invertebrates. Production/biomass and consumption/biomass reports were taken from other models from similar areas. Some studies showed wide variability in the values from these reports for the same species in different systems, and even wider among the same taxonomic group in different areas (AriasGonzales, 1984). Knowledge about each species' diet, productivity and consumption is necessary when grouping species, in order to achieve a better estimation of group's parameters.

Biomass of most fish and invertebrate species were estimated only in summer time (PELMED, MEDITS surveys) and should be completed with data concerning the other seasons. Migrations of some of fish species should also be better quantified.

For some species or groups, ecotrophic efficiencies (EE) were initially higher than 1 indicating that the initial biomass was probably underestimated. Their biomass had been estimated from the literature or assessed by experimental trawl surveys, which is not appropriate for all these species, as shown by the report between final biomass estimated by the model and initial biomass (Tables 2 and 4). Most of these groups are pelagic and demersal and their habitat is mainly located in the coastal area $(<10 \mathrm{~m})$ which is not covered by the scientific surveys. Therefore, input parameters $(\mathrm{P} / \mathrm{B}$ and $\mathrm{Q} / \mathrm{B})$ and the alternative input of $\mathrm{EE}$ taken from the literature were used to estimate the biomass of these groups using the food demands of the upper levels and fisheries landings. This method led to an increase in their biomass but also in the demand on other functional groups (zooplankton, echinoderms and fish), that are prey of the previous groups, and these biomasses were also raised (Table 4). More studies are necessary and other methods should also be implemented (virtual population analysis, acoustic methods, etc.) in order to improve these data.

We noted that the same difficulty of estimating the biomass of some demersal and benthic fish and invertebrates has been already stressed by other authors who modified initial estimated biomass of some functional groups (see Pinnegar, 2000; Sánchez and Olaso, 2004; Coll et al., 2006, 2007; Tsagarakis et al., 2010). 
Production and consumption parameters calculated using empiric equations (fish, birds and mammals) need to be validated with in situ measures on the studied species. The diet of some species (octopus, cuttlefish and squid, European pilchard, other small planktivorous fish species, Atlantic bluefin tuna, horse mackerels, mackerels, blue whiting, anglerfish, European conger) should be studied in the Gulf of Lions, as feeding behaviour may differ according to areas and to available food resources.

Bird and mammal abundance observations were made mainly in summer. These data need to be completed during all seasons and knowledge on their daily/seasonal behaviour; diet and migration patterns should also be improved.

The biomass of detritus originating from primary producers and estimated with an empiric equation was probably overestimated. Comparing this parameter with outputs from the other models (Symphonie-Eco3M) may improve the results. The lack of knowledge on the migration patterns of organisms and biomass accumulation in the system, probably increased the flows to detritus of the biomass non-consumed and non-exploited in the system.

There were wide differences in some species landings registered in the two data sources used in this study (Appendix 4). Auction sales databases underestimate catches because they included mainly data on catches from large boats (purse seine, trawls, some gillnets). On the other hand, the differences between auction sales databases and the detailed R3 report based on observed landings (Demaneche et al., 2009) were so wide for some species that we wonder whether they corresponded to reality, knowing that the number of observations was sometimes very low. The bottom trawling and mid-water trawling are merged in the analysis of gears impacts due to data availability. This is a limitation because these fleets likely target very different commercial species thus it is impeding to properly assess the role and impact of these two distinct fleets. In order to improve the Ecopath results and to build future Ecosim scenarios, improvements in landings databases are thus required. A big challenge, particularly in the Mediterranean Sea, is not only to include better catch, discards and effort data but also to assess and estimate Illegal Unreported Unregulated (IUU) fisheries considered one, if not the major, threat for marine biodiversity in the Mediterranean Sea.

Grouping of species according to diet should also be carefully analysed. For example in our study we first grouped blue whiting and Mediterranean horse mackerel, both consumers of macrozooplankton. Consumption in this group was high mainly because of the predation on the blue whiting but the biomass was mainly accounted for by the Mediterranean horse mackerel. The biomass of the blue whiting assessed by experimental trawl survey is highly underestimated because this species is mainly located in the water column on the continental slope and this area is difficult to sample. To balance the model, we had to raise the biomass of 
the group, but this resulted in cascade effects on the prey of the Mediterranean horse mackerel and the biomass of other functional groups was also raised. Finally we chose to treat separately the two species in this group. This is an example of the effect of grouping species. We have to keep in mind that the structure of this model is mainly based on functional groups constituted of many species, some of them, such as benthic invertebrates with ecological and biological traits that are still poorly known in this area, taken from other areas or estimated using empirical equations.

Previous models were confronted with similar difficulties concerning data sources and limits. It is important to highlight these limits and to try to improve the quality of data as in the future these models might probably be used as a basis for management decisions.

Although some deficiencies in available biological and landings data sources have been identified, the model quality was satisfactory (as indicated by the pedigree index of 0.67). The model is good enough to provide results on the structure and fonctionning of the ecosystem in the Gulf of Lions, on key species, flows and fishing impacts.

\section{Conclusion}

Ecosystem modelling can increase our understanding of fisheries impact on the whole food webs and not solely on targeted species. There is little consensus concerning the conceptual and analytical tools that should be used to study trophic interactions in ecosystems (Walters et al., 1997). The last two decades have seen a tremendous growth in the number and type of multispecies models designed for the study of fisheries impact (reviewed in Hollowed et al., 2000; Whipple et al., 2000), each having certain benefits and limitations. The mass-balance approach incorporated in the Ecopath software has been the most popular and is widely used to represent marine food webs and to address issues relevant to fisheries management (Pauly et al., 2000).

The present model constitutes the first mass-balance model to characterise the structure and the functioning of the food web in the Gulf of Lions and to quantify fisheries impact. It represents an important effort to synthesize the best available data on all the functional compartments of this ecosystem. The main results indicated that:

- Functional groups were organised in five trophic levels, with anglerfish, European conger, juvenile Atlantic bluefin tuna and European hake, as top predators.

- European pilchard and European anchovy represented the most important species in term of landings but also key link groups in the food web in term of consumption and flows between pelagic primary producers and consumers. Other fish species with high 
biomasses, such as Atlantic mackerel, fish (feeding on benthic crustaceans) and blue whiting had a high impact in the food web. Sea birds, dolphins and cuttlefish-squids represented keystone species.

- There was high coupling between the pelagic, the demersal and the benthic compartments. Demersal predators like hake thus played an important top-down control role, while the highest flows in term of biomass were due to a bottom-up control in relation to the phytoplankton productivity.

- Large trawls (24-40 m) had the most negative impact on the entire ecosystem and on the majority of the groups in the food web, while small purse seines (12-24 m) had the lowest impact.

- Indices calculated by the model and the percentage of fish production exploited by fisheries showed that the Gulf of Lions ecosystem was highly exploited.

The advantages of having an Ecopath model for the Gulf of Lions is to give a global image of the ecosystem, to identify important elements of its structure, intections between groups and species and also to highlight incomplete and missing data on some groups in order to orientate future studies and improve these data and model analysis.

\section{Acknowledgements}

This work was supported by the AMPED project (www.amped.ird.fr) through a grant from the French National Research Agency (ANR), Systerra Programme, grant number ANR-08STRA-03. D. Banaru had of a post-doc fellowship co-funded by the ANR “AMPED” and IFREMER.

Authors address special thanks to B. Guijarro from IEO for providing information concerning Spanish catches in the Gulf of Lions, to D. Kaplan, H. Demarcq and M. Harmelin-Vivien for their constructive remarks on the manuscript and to M. Paul for the English corrections. We are gratefull to the editor and the reviewers for the valuable comments on our manuscript which help us to improve it. 


\section{References}

Aldebert, Y., Recasens, L., 1996. Comparison of methods for stock assessment of European hake Merluccius merluccius in the gulf of Lion (Northwestern Mediterranean). Aquatic Living Resources, 9: 13-22.

Allen, R.R., 1971. Relation between production and biomass. Journal of Fisheries Research Board of Canada, 28: 1573-1581.

Alves, D.M., Cristo, M., Sendao, J., Borges, T.C., 2006. Diet of the cuttlefish Sepia officinalis (Cephalopoda : Seplidae) off the south coast of Portugal (eastern Algarve). Journal of the Marine Biological Association of the United Kingdom, 86(2): 429-436.

Agostini, V.N., Bakun, A., 2002. "Ocean triads" in the Mediterranean Sea: Physical mechanisms potentially structuring reproductive habitat suitability (with example application to European anchovy). Fisheries Oceanography, 11(3):129-142.

Arcos, J.M., 1999. Foraging ecology of seabirds at sea: significance of commercial fisheries in the NW Mediterranean. Ph.D. thesis Universitat de Barcelona. 114 pp.

Arias-González, J.E., 1984. Fonctionnement trophique d'un écosystème récifal : secteur de Tiahura, île de Moorea, Polynesie française. $\mathrm{PhD}$ thesis, Centre de Biologie et d'Ecologie tropicale et Méditerranéenne. 358 pp.

Astruc, G., 2005. Exploitation des chaines trophiques marines de Méditerranée par les populations de cétacés. Mémoire de l'Ecole Pratique des Hautes Etudes, Montpellier. $188 \mathrm{pp}$.

Avsar, D., 1995. Population parameters of sprat (Sprattus sprattus phalericus RISSO) from the Turkish Black Sea coast. Fisheries Research, 21(3-4): 437-453.

Baklouti, M., Faure, V., Pawlowski, L., Sciandra A., 2006. Investigation and sensitivity analysis of a mechanistic phytoplankton model implemented in a new modular numerical tool (Eco3M) dedicated to biogeochemical modelling. Progress in Ocenography, 71: 34-58.

Bamstedt, U., Karlson, K., 1998. Euphausiid predation on copepods in coastal waters of the Northeast Atlantic. Marine Ecology-Progress Series, 172: 149-168.

Baird, D., McGlade, J.M., Ulanowicz, R.E., 1991. The comparative ecology of six marine ecosystems. Philosophical Transactions of the Royal Society of London, 333: 15-29.

Banaru, D., 2008 Influence des apports du Danube sur les réseaux trophiques des poissons des côtes roumaines (Mer Noire). Thèse de doctorat Université Aix-Marseille II. 309 pp.

Banaru, D., Harmelin-Vivien, M., 2009. Feeding behaviour of Black Sea bottom fishes: Did it change over time? Acta Oecologica-International Journal of Ecology, 35(6): 769-777. 
Banaru, D., Dekeyser, I., Imbert, G., Laubier, L., 2010a. Atlantic bluefin tuna (Thunnus thynnus) and swordfish (Xiphias gladius) catch distributions observed during tunaye fishery in the Northwestern Mediterranean Sea (2000-2003 database). Journal of Oceanography, Research and Data, 3(1): 1-5.

Banaru, D., Harmelin-Vivien, M., Boudouresque C.-F., 2010b. Man induced change in community control in the north-western Black Sea: the top-down bottom-up balance. Marine Environmental Research, 69(4): 262-275.

Bautista-Vega, A.A., Letourneur, Y., Harmelin-Vivien, M., Salen-Picard, C., 2008. Difference in diet and size-related trophic level in two sympatric fish species, the red mullets Mullus barbatus and Mullus surmuletus, in the Gulf of Lions (north-west Mediterranean Sea). Journal of Fish Biology, 73(10): 2402-2420.

Bas, C., Maynou, F., Sardà, F., Lleonart, J., 2003. Variacions demogràfiques a les poblacions d'espècies demersals explotades: els darrers quaranta anys a Blanes i Barcelona. Institut d'Estudis Catalans. Secció de Ciències Biologia, 135: 1-202.

Bearzi, G., Politi, E., Agazzi, F., Azzellino, A., 2006. Prey depletion caused by overfishing and the decline of marine megafauna in eastern Ionian Sea coastal waters (central Mediterranean). Biological Conservation, 127(4): 373-382.

Beaubrun, P.C., 1995. Atlas préliminaire de distribution de cétacés en Méditerranée. CIESM, Musée Océanographique de Monaco. 87 pp.

Bell, J.D., Harmelin-Vivien, M.L., 1983. Fish fauna of French Mediterranean Posidonia oceanica seagrass meadows. II: feeding habits. Tethys, 11(1): 1-14.

Bertrand, J.A., Aldebert, Y., Souplet, A., 1998. Temporal variability of demersal species in the Gulf of Lions from trawl surveys (1983-1997). IFREMER Actes de Colloques, 26 : 153-164.

Bonhommeau, S., Farrugio, H., Poisson, F., Fromentin, J.M., 2010. Aerial surveys of bluefin tuna in the western Mediterranean Sea: retrospective, prospective, perspective. Collection Volumes Scientific Papers ICCAT, 65(3): 801-811.

Boucher, J., Thiriot, A., 1972. Zooplancton et micronecton estivaux des deux cents premiers mètres en Méditerranée Occidentale. Marine Biology, 15: 47-56.

Boudouresque, C.F., Mayot, N., Pergent, G., 2006. The outstanding traits of the functioning of the Posidonia oceanica seagrass ecosystem. Biologia Marina Mediterranea, 13(4): 109-113.

Bozzano, A., Sarda F., 2002. Fishery discard consumption rate and scavenging activity in the northwestern Mediterranean Sea. Ices Journal of Marine Science, 59(1): 15-28. 
Bowman, R.E., Stillwell, C.E., Michaels, W.L., Grosslein, M.D., 2000. Food of northwest Atlantic fishes and two common species of squid. NOAA Technical Memorandum NMFS-NE-155. 138 pp.

Cadiou, B., Pons, J.-M., Yésou, P., 2004. Oiseaux marins nicheurs de France métropolitaine (1960-2000). Eds. Biotope, Mèze. 218 pp.

Calbet, A., Broglio, E., Saiz, E., Alcaraz, M., 2002. Low grazing impact of mesozooplancton on the microbial communities of the Alboran Sea: a possible case of inhibitory effects by the toxic dinoflagellate Gymnodinium catenatum. Aquatic Microbial Ecology, 26: 235-246.

Carlier, A., Riera, P., Amouroux, J.M., Bodiou, J.Y., Gremare, A., 2007. Benthic trophic network in the Bay of Banyuls-sur-Mer (northwest Mediterranean, France): An assessment based on stable carbon and nitrogen isotopes analysis. Estuarine Coastal and Shelf Science, 72(1-2): 1-15.

Campillo, A., 1992. Les pêcheries françaises de Méditerranée: synthèse des connaissances. IFREMER RI DRV 92-019 RH/Sete, http://archimer.ifremer.fr/doc/00000/1125/. 206 pp.

Cartes, J.E., 1998. Dynamics of the bathyal Benthic Boundary Layer in the northwestern Mediterranean: depth and temporal variations in macrofaunal-megafaunal communities and their possible connections within deep-sea trophic webs. Progress in Oceanography, 41(1): 111-139.

Cartes, J.E., Madurell, T., Fanelli, E., López-Jurado, J.L., 2008. Dynamics of suprabenthoszooplankton communities around the Balearic Islands (western Mediterranean): Influence of environmental variables and effects on the biological cycle of Aristeus antennatus. Journal of Marine Systems, 71(3-4): 316-335.

Cartes, J.E., Sorbe, J.C., 1999. Estimating secondary production in bathyal suprabenthic peracarid crustaceans from the Catalan Sea slope (western Mediterranean; 391-1255 m). Journal of Experimental Marine Biology and Ecology, 239(2): 195-210.

Cau, A., Manconi, P., 1984. Relationship of feeding, reproductive-cycle and bathymetric distribution in Conger conger. Marine Biology, 81(2): 147-151.

Champalbert, G., 1996. Characteristics of zooplankton standings stock and communities in the Western Mediterranean sea: Relations to hydrology. Scientia Marina, 60(2): 97-113.

Christaki, U., Courties, C., Joux, F., Jeffrey, W.H., Neveux, J., Naudin, J.J., 2009.

Community structure and trophic role of ciliates and heterotrophic nanoflagellates in Rhone River diluted mesoscale structures (NW Mediterranean Sea). Aquatic Microbial Ecology, 57(3): 263-277. 
Christensen, V., 1995. Ecosystem maturity - towards quantification. Ecological Modelling, 77: 3-32.

Christensen, V., Pauly, D., 1991. A guide to the ECOPATH II program (version 2.0). ICLARM Software 6, International Centre for Living Aquatic Resources Management, Manila, Philippines. 71 pp.

Christensen, V., Pauly, D., 1993. Flow characteristics of aquatic ecosystems. In Trophic Models of Aquatic Ecosystems. Ed. by Christensen, V., and Pauly, D. ICLARM Conference Proceedings, Manila, 26: 338-352.

Christensen, V., Guenette, S., Heymans, J.J., Walters, C., Zeller, D., Pauly, D., 2003. Hundred-year decline of North-Atlantic predatory fishes. Fish and Fisheries, 4: 1-24.

Christensen, V., Walters, C., 2004. Ecopath with Ecosim: methods, capabilities and limitations. Ecological Modelling, 172(2-4): 109-139.

Christensen, V., Walters, C.J., Pauly, D., 2005. Ecopath with Ecosim: a user's guide [online]. Fishery Centre, The University of British Columbia, Vancouver, B. C. Available from http://www.ecopath.org/modules/Support/Helpfile/EwEUserGuide51.pdf.

Christensen, V., Walters, C., Pauly, D., Forrest, R., 2008. Ecopath with Ecosim version 6. User Guide - November 2008. Lenfest Ocean Futures Project 2008, 235 pp.

Coelho, M., Domingues, P., Balguerias, E., Fernandez, M., Andrade, J.P., 1997. A comparative study of the diet of Loligo vulgaris (Lamarck, 1799) (Mollusca: Cephalopoda) from the south coast of Portugal and the saharan bank (Central-East Atlantic). Fisheries Research, 29(3): 245-255.

Coll., M., 2006. Modelización de flujos tróficos y uso de indicadores ecológicos como aproximación al estudio de las pesquerías mediterráneas. $\mathrm{PhD}$ reportó, Departamento de Recursos Marinos Renovables Instituto de Ciencias del Mar. 538 pp.

Coll, M., Palomera, I., Trudela, S., Sarda, F., 2006. Trophic flows, ecosystem structure and fishing impacts in the South Catalan Sea, Northwestern Mediterranean. Journal of Marine Systems, 59(1-2): 63-96.

Coll, M., Santojanni, A., Palomera, I., Trudela, S., Arneri, E., 2007. An ecological model of the Northern and Central Adriatic Sea: Analysis of ecosystem structure and fishing impacts. Journal of Marine Systems, 67(1-2): 119-154.

Coll, M., Santojanni, A., Palomera, I., Arneri, E., 2009. Food-web changes in the Adriatic Sea over the last three decades. Marine Ecology-Progress Series, 381: 17-37.

Coll M., Libralato S., 2011. Contributions of food web modelling to the ecosystem approach to marine resource management in the Mediterranean Sea. Fish and Fisheries, DOI: 10.1111/j.1467-2979.2011.00420.x 
Conéjéro, S., 1998. Application de deux méthodologies à bord d'un chalutier pour étudier la distribution des oiseaux marins. Distorsions révélées dans le golfe du Lion en période estivale. Mémoire de l'Ecole Pratique des Hautes Etudes, Montpellier. 131 pp.

Contino, F., 2004. Contenus stomacaux des thons rouges (Thunnus thynnus, L. 1758) capturés par les thonailles dans le basin provençal. Rapport de stage de maîtrise, Centre d'Océanologie de Marseille, Université Aix-Marseille II. 26 pp.

Costa, M.J., 1988. Écologie alimentaire des poissons de l'estuarie du Tage. Cybium, 12(4): 301-320.

Cramm, P., Ravayrol, A., Devaud, L., 1998. Sites de nidification et d'alimentation des populations de sternes nicheuses des étangs sud montpelliérains. Conservatoire du Littoral, Rapport Life. 40 pp.

Crawford, R.J.M., Ryan, P.G., Williams, A.J., 1991. Seabird consumption and production in the Benguela and Western Agulhas ecosystems. South African Journal of Marine Science-Suid-Afrikaanse Tydskrif Vir Seewetenskap, 11: 357-375.

Cury, P., Bakun, A., Crawford, R.J.M., Jarre, A., Quinones, R.A., Shannon, L.J., Verheye, H.M., 2000. Small pelagic in upwelling systems: patterns of interaction and structural changes in "wasp-waist" ecosystems. ICES Journal of Marine Science, 57: 603-618.

Cury, P.M., Shannon, L.J., Roux, J-P., Daskalov, G.M., Jarre, A., Moloney, C.L., Pauly, D., 2005. Trophodynamic indicators for an ecosystem approach to fisheries. ICES Journal of Marine Science, 62(3): 430-442.

Dalsgaard, J., Pauly D., 1997. Preliminary mass-balance modelo of Prince William Sound, Alaska, for the pre-spill period, 1980-1989. Fisheries Centre Research Report, 5(2): 134.

Danilova, M.M., 1991. Diet of juvenile silversides, Atherina boyeri, from the Black Sea. Journal of Ichthyology, 31(3): 137-147.

Darnaude, A.M., Salen-Picard, C., Harmelin-Vivien, M.L., 2004a. Depth variation in terrestrial particulate organic matter exploitation by marine coastal benthic communities off the Rhone River delta (NW Mediterranean). Marine Ecology-Progress Series, 275: 47-57.

Darnaude, A.M., Salen-Picard, C., Polunin, N.V.C., Harmelin-Vivien, M.L., 2004b. Trophodynamic linkage between river runoff and coastal fishery yield elucidated by stable isotope data in the Gulf of Lions (NW Mediterranean). Oecologia, 138(3): 325332.

Daskalov, G.M., 2002. Overfishing drives a trophic cascade in the Black Sea. Marine Ecology Progress Series, 225: 53-63. 
Dauvin, J.C., 1985. Dynamics and production of a population of Venus ovata Pennant (Mollusca, Bivalva) from the Bay of Morlaix (Western English-Channel). Journal of Experimental Marine Biology and Ecology, 91(1-2): 109-123.

De Bovée, F., Guidi, L.D., Soyer, J., 1990. Quantitative Distribution of Deep-Sea Meiobenthos in the Northwestern Mediterranean (Gulf of Lions). Continental Shelf Research, 10(9-11): 1123-1145.

Decembrini, F., Caroppo, C., Azzaro M., 2009. Size structure and production of phytoplankton community and carbon pathways channelling in the Southern Tyrrhenian Sea (Western Mediterranean). Deep Sea Research Part II: Topical Studies in Oceanography Multi-disciplinary forays into the south Tyrrhenian Sea - 2005 CIESM/SUB cruises - CIESM/SUB south Tyrrhenian, 56(11-12): 687-699.

Demaneche, S., Merrien, C., Berthou, P., Lespagnol, P., 2009. Rapport R3 Méditerranée continentale, échantillonnage des marées au débarquement. Méthode d'élévation et évaluation des captures et de l'effort de pêche des flottilles de la façade Méditerranée continentale sur la période 2007-2008. Programme P6 AESYPECHE "Approche écosystémique de l'halieutique" Projet Système d'Informations Halieutiques SIH, IFREMER, France, 54 pp.

Demirhan, S.A., Semih Engin, S., Seyhan, K., Akamca, E., 2005. Some biological aspects of thornback ray (Raja clavata L., 1758) in the southeastern Black Sea. Turkish Journal of Fisheries and Aquatic Sciences, 5: 75-83.

Diaz F., Campbell, R., Hu, Z., Estournel, C., Petrenko, A., Modelling the biogeochemical functioning of the mesoscale eddies in the Gulf of Lion (NW Mediterranean). Submitted to Ecological Modelling.

Dieng, A., Bakha Yokho, M., Diop, D., 2000. Le régime alimentaire du poulpe (Octopus vulgaris) sur les côtes du Sénégal. Archives Scientifiques du Centre de Recherches Océanographiques de Dakar - Thiaroye. 14 pp.

Eiane, K., Tande, K., 2009. Meso and macrozooplankton. In Ecosystem Barents Sea, pp 209234. Ed. by Johnsen, G., Sakshaug, E., and Kovacs, K. Tapir Academic Press, Trondheim, Norwey.

Eisenhauer, L., Carlotti, F., Baklouti, M., Diaz, F., 2009. Zooplankton population model coupled to a biogeochemical model of the North Western Mediterranean Sea ecosystem. Ecological Modelling, 220: 2865-2876.

Farrugio, H., Alvarez Prado, F., Lleonart, J., De Ranieri, S., 1991. Etude pour l'aménagement et la gestion des pêches en Méditerranée occidentale. Rapport final Commission des Communautés Européennes, Contrat no. MA-1-232, 454 pp. 
FAO, 1995. Code of Conduct for Responsible Fisheries. FAO, Rome, Italy.

FAO, 2002. The Ecosystem Approach to Fisheries, draft 2. Fisheries FAO guidelines on the ecosystem approach on fisheries. Food and Agriculture Organization of the United Nations. Rome, 2002. Reykjavik, 16-19 September 2002.

FAO, 2009. Rapport de la trente-troisième session de la Commission générale des pêches pour la Méditerranée (CGPM). Tunis, 23-27 mars 2009. 132 pp.

Farrugio, H., Oliver, P., Biagi, F., 1993. An overview of the history, knowledge, recent and future research trends in the Mediterranean fisheries. Scientia Marina, 57(2-3): 105-119.

Fehri-Bedoui, R., Mokrani, E., Ben Hassine, O.K., 2009. Feeding habits of Pagellus acarne (Sparidae) in the Gulf of Tunis, central Mediterranean. Scientia Marina, 7(4): 667-678.

Finn, J.T., 1976. Measures of ecosystem structure and functioning derived from analysis of flows. Journal of Theoretical Biology, 56: 363-380.

Furnestin, M.L., 1960. Zooplancton du golfe du Lion et de la côte orientale de Corse. Revue de Travaux de l'Institut des Pêches maritimes, 24(2): 153-252.

Garrido, S., Ben-Hamadou, R., Oliveira, P.B., Cunha, M.E., Chicharo, M.A., van der Lingen, C.D., 2008. Diet and feeding intensity of sardine Sardina pilchardus: correlation with satellite-derived chlorophyll data. Marine Ecology-Progress Series, 354: 245-256.

Gaudy, R., Youssara, F., Diaz, F., Raimbault, P., 2003. Biomass, metabolism and nutrition of zooplankton in the Gulf of Lions (NW Mediterranean). Oceanologica Acta, 26(4): 357372.

Geistdoerfer, P., 1983. Feeding-Habits of the Blue Whiting Micromesistus poutassou (Risso, 1826) (Teleosteens, Gadidae) in the Northeastern Atlantic-Ocean. Journal Du Conseil, 41(1): 67-75.

GFCM, 2010. Report of the $12^{\text {th }}$ session of the scientific advisory committee (SAC). Budva, Montenegro, 25-29 January 2010. 212 pp.

Gonzalez-Solis, J., Oro, D., Jover, L., Ruiz, X., Pedrocchi, V., 1997. Trophic niche width and overlap of two sympatric gulls in the southwestern Mediterranean. Oecologia, 112(1): 75-80.

Graham, W.M., Kroutil, R.M., 2001. Size-based prey selectivity and dietary shifts in the jellyfish, Aurelia aurita. Journal of Plankton Research, 23(1): 67-74.

Hall, S.J., 1999. The Effects of Fishing on Marine Ecosystems and Communities. Fish Biology and Aquatic Resources. Series Blackwell Science. 274 pp.

Harmelin-Vivien, M., Loizeau V., Mellon, C., Beker, B., Arlhac, D., Bodiguel, X., Ferraton, F., Hermand, R., Philippon, X., Salen-Picard, C., 2008. Comparison of C and N stable 
isotope ratios between surface particulate organic matter and microphytoplankton in the Gulf of Lions (NW Mediterranean). Continental Shelf Research, 28(15): 1911-1919. Harmelin-Vivien, M., Dierking, J., Bănaru, D., Fontaine, M.F., Arlhac, D., 2010. Seasonal variation in stable $\mathrm{C}$ and $\mathrm{N}$ isotope ratios of the Rhone River inputs to the Mediterranean Sea (2004-2005). Biogeochemistry, 100(1-3): 139-150.

Havelange, S., Lepoint, G., Dauby, P., Bouquegneau, J.M., 1997. Feeding of the sparid fish Sarpa salpa in a seagrass ecosystem: diet and carbon flux. Marine EcologyPubblicazioni Della Stazione Zoologica Di Napoli I, 18(4): 289-297.

Hermand, R., Salen-Picard, C., Alliot, E., Degiovanni, C., 2008. Macrofaunal density, biomass and composition of estuarine sediments and their relationship to the river plume of the Rhone River (NW Mediterranean). Estuarine Coastal and Shelf Science, 79(3): 367-376.

Hollowed, A.B., Bax, N., Beamish, R., Collie, J., Fogarty, M., Livingston, P., Pope, J., Rice, J.C., 2000. Are multispecies models an improvement on single-species models for measuring fishing impacts on marine ecosystems? ICES Journal of Marine Science, 57: 707-719.

Hu, Z.Y., Doglioli, A.M., Petrenko, A.A., Marsaleix, P., Dekeyser, I., 2009. Numerical simulations of eddies in the Gulf of Lion. Ocean Modelling, 28(4): 203-208.

IFREMER, 2009. Panorama des rejets dans les pêcheries françaises. Rapport OBSMER. 66 pp.

Imbert, G., Contino, F., Astruc, G., Laubier, L., Relini, G., 2007. Prélèvement d'échantillons cétologiques et analyse de contenus stomacaux, pp 75-116. In La thonaille ou courantille volante. Rapport final au Conseil Régional Provence-Alpes-Côte d'Azur. Eds. Méditerranée 2000, Cannes.

Innes, S., Lavigne, D.M., Earle, W.M., Kovacs, K.M., 1987. Feeding rates of seals and whales. Journal of Animal Ecology, 56: 115-130.

Javidpour, J., Molinero, J.C., Lehmann, A., Hansen T., Sommer, A., 2009. Annual assessment of the predation of Mnemiopsis leidyi in a new invaded environment, the Kiel Fjord (Western Baltic Sea): a matter of concern? Journal of Plankton Research, 31(7): 729738.

Jackson, J.B.C., Kirby, M.X., Berger, W.H., Bjorndal, K.A., Botsford, L.W., Bourque, B.J., Bradbury, R.H., Cooke, R., Erlandson, J., Estes, J.A., Hughes, T.P., Kidwell, S., Lange, C.B., Lenihan, H.S., Pandolfi, J.M., Peterson, C.H., Steneck, R.S., Tegner, M.J., Warner, R.R., 2001. Historical overfishing and the recent collapse of coastal ecosystems. Science, 293: 629-638. 
Jennings, S., Kaiser, M.J., 1998. The effects of fishing on marine ecosystems. Advances in Marine Biology, 34: 201-351.

Kallianiotis, A., Torre, M., Argyri, A., 2005 Age, growth, mortality, reproduction, and feeding habits of the striped seabream, Lithognathus mormyrus (Pisces: Sparidae), in the coastal waters of the Thracian Sea, Greece. Scientia Marina, 69(3): 391-404.

Kavanagh, P., Newlands, N., Christensen, V., Pauly, D., 2004. Automated parameter optimization for Ecopath ecosystem models. Ecological Modelling, 172: 141-150.

Kulka, D.W., Corey, S., 1982. Length and weight relationships of Euphausiids and caloric values of Meganyctiphanes norvegica (M. Sars) in the Bay of Fundy. Journal of Crustacean Biology, 2(2): 239-247.

Labrune, C., Gremare, A., Guizien, K., Amouroux, J.M., 2007. Long-term comparison of soft bottom macrobenthos in the Bay of Banyuls-sur-Mer (north-western Mediterranean Sea): A reappraisal. Journal of Sea Research, 58(2): 125-143.

Labat, J.-P., Cuzin-Roudy, J., 1996. Population dynamics of the krill Meganyctiphanes norvegica (Sars) (Crustacea: Euphausiacea) in the Ligurian Sea (NW Mediterranean Sea). Size structure, growth and mortality modelling. Journal of Plankton Research, 18: 2295-2312.

Lalli, C.M., Parsons, T.R., 1993. Biological oceanography: an introduction. Pergamon Press, Oxford. pp. 296.

Lee, J.Y., 1961. La sardine du golfe du lion (Sardina pilchardus sardina REGAN). Revue des Travaux de l'Institut des Pêches Maritimes, 25(4) : 418-513. http://archimer.ifremer.fr/doc/00000/4266/

Lefevre, D., Minas, H.J., Minas, M., Robinson, C., Williams, P.J.LeB., Woodward, E.M.S., 1997. Review of gross community production, primary production, net community production and dark community respiration in the Gulf of Lions. Deep Sea Research Part II: Topical Studies in Oceanography, 44(3-4): 801-819.

Libralato, S., Pastres, R., Pranovi, F., Raicevich, S., Granzotto, A., Giovanardi, O., Torricelli, P., 2002. Comparison between the energy flow networks of two habitats in the Venice lagoon. P.S.Z.N. Marine Ecology, 23: 228-236.

Libralato, S., Christensen, V., Pauly, D., 2006. A method for identifying keystone species in food web models. Ecological Modelling, 195(3-4): 153-171.

Lindeman, R.L., 1942. The trophic-dynamic aspect of ecology. Ecology, 23: 399-418.

Link, J., 2009. In: Palomares, M.L.D., Morissette, L., Cisneros-Montemayor, A., Varkey, D., Coll, M., Piroddi, C. (eds.), Ecopath 25 Years Conference Proceedings: Extended 
Abstracts, pp. 88-89. Fisheries Centre Research Reports 17(3). Fisheries Centre, University of British Columbia [ISSN 1198-6727]. 165 p.

Lleonart, J., 1990. La pesquería de Cataluña y Valencia: descripción global y planteamiento de bases para su seguimiento. Informe Final del Proyecto 1989/3. CE-Dirección General de Pesca (XIV), vol I-II, Barcelona.

Lleonart, J., Maynou, F., 2003. Fish stock assessment in the Mediterranean: state of the art. In: Ulltang, O., Blom, G. (Eds.), Fish stock assessments and predictions: integrating relevant knowledge, Scientia Marina vol. 67, Suppl. 1, pp. 37-49.

Louzao, M., Becares, J., Rodriguez, B., Hyrenbach, K.D., Ruiz, A., Arcos, J.M., 2009. Combining vessel-based surveys and tracking data to identify key marine areas for seabirds. Marine Ecology-Progress Series, 391: 183-197.

Maynou, F., Cartes, J.E., 1998. Daily ration estimates and comparative study of food consumption in nine species of deep-water decapod crustaceans of the NW Mediterranean. Marine Ecology-Progress Series, 171: 221-231.

Margalef, R., 1968. Perspectives in Theoretical Ecology. The University of Chicago Press, Chicago-London. $111 \mathrm{pp}$.

Margalef, R., 1985. Introduction to the Mediterranean. In Key Environments: Western Mediterranean. Ed. By Margalef, R. Pergamon Press, Oxford. pp. 1-16.

Marty, J.C., Chiaverini, J., 2002. Seasonal and interannual variations in phytoplankton production at DYFAMED time-series station, northwestern Mediterranean Sea. DeepSea Research Part II-Topical Studies in Oceanography, 49(11): 2017-2030.

Marty, J.-C., Garcia, N., Raimbault, P., 2008. Phytoplankton dynamics and primary production under late summer conditions in the NW Mediterranean Sea. Deep Sea Research Part I: Oceanographic Research Papers, 55(9): 1131-1149.

Macpherson, E., 1978. Régimen alimentario de Phycis blennoides (Brünich) y Antonogadus megalokynodon (Kolombatovich) (Pisces: Gadidae) en el Mediterráneo occidental. Investigations Pesqua, 42: 455-466.

McClanahan, T.R., Sala, E., 1997. A Mediterranean rocky-bottom ecosystem fisheries model. Ecological Modelling, 104: 145-164.

Mellon-Duval, C., de Pontual, H., Metral, L., Quemener, L., 2009. Growth of European hake (Merluccius merluccius) in the Gulf of Lions based on conventional tagging. ICES Journal of Marine Science, 67(1): 62-70.

Millot, C., 1999. Circulation in the Western Mediterranean Sea. Journal of Marine Systems 20(1-4), 423-442. 
Moreno-Amich, R., 1992. Feeding-habits of red gurnard, Aspitrigla cuculus (L 1758)

(Scorpaeniformes, Triglidae), along the Catalan coast (Northwestern Mediterranean). Hydrobiologia, 228(3): 175-184.

Morissette, L., 2007. Complexity, cost and quality of ecosystem models and their impact on resiliance: a comparative analysis, with emphasis on marine mammals and the gulf of St. Lawrence. Ph.D. thesis, University of British Columbia, Vancouver, 260 pp. http://www2.fisheries. com/archive/grad/abstracts/lmphdthesis.pdf.

Morote, E., Olivar, M.P., Villate, F., Uriarte, I., 2008. Diet of round sardinella, Sardinella aurita, larvae in relation to plankton availability in the NW Mediterranean. Journal of Plankton Research, 30(7): 807-816.

Morte, S., Redon, M.J., Sanz-Brau, A., 1999. Feeding ecology of two megrims Lepidorhombus doscii and Lepidorhombus whiffiagonis in the western Mediterranean (Gulf of Valencia, Spain). Journal of the Marine Biological Association of the United Kingdom, 79(1): 161-169.

Nilsson, S.G. Nilsson, I.N., 1976. Number, food and consumption, and fish predation by birds in Lake Mockeln, Southern Sweden. Ornis Scandinavica, 7: 61-70.

Odum, E.P., 1969. The strategy of ecosystem development. Science, 104: 262-270.

Odum, W.E., Heald, E.J., 1975. The detritus-based food web of an estuarine mangrove community. In Estuarine Research, vol. 1. Ed. by Cronin, L. E. Academic Press, New York.

Olaso, I., Velasco, F., Perez, N., 1998. Importance of discarded blue whiting (Micromesistius poutassou) in the diet of lesser spotted dogfish (Scyliorhinus canicula) in the Cantabrian Sea. ICES Journal of Marine Science, 55(3): 331-341.

Olaso, I., Gutiérrez, J.L., Villamor, B., Carrera, P., Valdés, L., Abaunza, P., 2005. Seasonal changes in the north-eastern Atlantic mackerel diet (Scomber scombrus) in the north of Spain (ICES Division VIIIc). Journal of the Marine Biological Association of the UK, 85(02): 415-418.

Örek, H., 2000. An application of mass balance Ecopath model to the trophic structure in the Black Sea after anchovy collapse. In Marine Science. Middle East Technical University. 119 pp.

Oven, L.S., Shevchenko, N.F., Giragosov, V.E., 1997. Size-age composition, feeding, and reproduction of Sprattus sprattus phalericus (Clupeidae) in different sites of the Black Sea. Journal of Ichthyology , 37(9): 769-778. 
Palomares, M.L.D., Pauly, D., 1998. Predicting food consumption of fish populations as functions of mortality, food type, morphometrics, temperature and salinity. Marine and Freshwater Research, 49(5): 447-453.

Papaconstantinou, C., Farrugio, H., 2000. Fisheries in the Mediterranean. Mediterranean Marine Science, 1(1): 5-18.

Pasquaud, S., Elie, P., Jeantet, C., Billy, I., Martinez, P., Girardin, M., 2008. A preliminary investigation of the fish food web in the Gironde estuary, France, using dietary and stable isotope analyses. Estuarine Coastal and Shelf Science, 78(2): 267-279.

Pauly, D., Christensen, V., 1995. Primary production required to sustain global fisheries. Nature, 374: 255-257.

Pauly, D., Soriano, M., Palomares, M.L., 1993. On improving the construction, parametrization and interpretation of steady-state multispecies models. In Trophic models of aquatic ecosystems. Ed. by Christensen, V. and Pauly, D. ICLARM Conference Proceedings, vol. 26, 390 p.

Pauly, D., Christensen, V., Dalsgaard, A., Froese, R., Torres, J., 1998. Fishing down marine food webs. Science, 279 (5352), 860-863.

Pauly, D., Christensen, V., Walters, C., 2000. Ecopath, ecosim and ecospace as tools for evaluating ecosystem impact of fisheries. ICES Journal of Marine Science, 57: 697-706.

Pauly, D., Graham, W., Libralato, S., Morrissette, L., Palomares, M.L.D., 2009. Jellyfish in ecosystems, online databases, and ecosystem models. Hydrobiologia, 616: 67-85.

Pergent, G., Romero, J., Pergent-Martini, C., Mateo, M.A., Boudouresque, C.F., 1994. Primary Production, Stocks and Fluxes in the Mediterranean Seagrass Posidonia oceanica. Marine Ecology-Progress Series, 106(1-2): 139-146.

Pergent-Martini C., Rico-Raimondino V., Pergent, V., 1994. Primary production of Posidonia oceanica in the Mediterranean Basin. Marine Biology, 120: 9-15.

Pergent, G., Rico-Raimondino, V., Pergent-Martini, C., 1997. Fate of primary production in Posidonia oceanica meadows of the Mediterranean. Aquatic Botany, 59(3-4): 307-321.

Petrenko, A.A., Leredde, Y., Marsaleix, P., 2005. Circulation in a stratified and windforced Gulf of Lions, NW Mediterranean Sea: in situ and modelling data. Continental Shelf Research, 25: 7-27.

Pinnegar, J.K., 2000. Planktivorous fishes: links between the Mediterranean littoral and pelagic. $\mathrm{PhD}$ thesis, University of Newcastle upon Tyne. $208 \mathrm{pp}$.

Pinnegar, J.K., Polunin, N.V.C., 2004. Predicting indirect effects of fishing in the Mediterranean rocky littoral communities using a dynamic simulation model. Ecological Modelling, 172 (2-4): 249-268. 
Pisarevskaya, I.I., Aksenova, E.O., 1991. Feeding of Black Sea mullets during early ontogeny. Journal of Ichthyology, 31(3): 22-30.

Plagányi, É., 2007. Models for an Ecosystem Approach to Fisheries, FAO Food and Agriculture Organization, Fisheries Technical Paper, Rome, Italy, no. 477, 108 pp.

Plante-Cuny, M.-R., Bodoy, A. 1987. Biomasse et production primaire du phytoplancton et du microphytobenthos de deux biotopes sableux (Golfe de Fos, France). Oceanologica Acta, 10(2): 223-237.

Plounevez, S., Champalbert, G., 2000. Diet, feeding behaviour and trophic activity of the anchovy (Engraulis encrasicolus L.) in the Gulf of Lions (Mediterranean Sea). Oceanologica Acta, 23(2): 175-192.

Preciado, I., Velasco, F., Olaso, I., Landa, J., 2006. Feeding ecology of black anglerfish Lophius budegassa: seasonal, bathymetric and ontogenetic shifts. Journal of the Marine Biological Association of the United Kingdom, 86(4): 877-884.

Ratsimbazafy, R., Boucher, G., Dauvin, J.C., 1994. Indirect measurement of the biomass of nematodes from the subtidal meiobenthos of the English-Channel. Cahiers De Biologie Marine, 35(4): 511-523.

Razouls, C., Kouwenberg, J.H.M., 1993. Spatial-distribution and seasonal-variation of mesozooplankton biomass in the Gulf-of-Lions (Northwestern Mediterranean). Oceanologica Acta, 16(4): 393-401.

Riaux-Gobin, C., Vetion, G., Neveux, J., Duchene, J.-C., 1998. Microphytobenthos and phytoplankton in Banyuls bay (Gulf of Lions): standing stocks and hydroclimatic factors. Vie et milieu, 48(1): 1-13.

Rico-Raimondino, V., 1995. Contribution à l'étude des stocks et flux d'éléments dans l'herbiers à Posidonia oceanica. Thèse de Doctorat. Univ. Aix-Marseille II, France. 248 p.

Ripoll, T., Dhermain, F., Barril, D., Trucchi, R., Bonsignori, B., Roussel, E., David, L., Beaubrun, P., 2001. First summer population estimate of bottlenose dolphins along the North-western coasts on the occidental Mediterranean basin. European Research on Cetaceans, 15: 393-396.

Romero, J., 2004. Las praderas de Fanerogamas marinas. La produccion primaria y su destino. Caracteristicas de los restos de la planta, pp: 74-81. In Praderas y bosques marinos de Andalucia, Consejaria de Medio Ambiente. Ed. by Luque, A. A., and Templado J. Junta de Andalucia publicación, Sevilla.

Ropert, M., 1999. Caractérisation et déterminisme du développement d'une population de l'annélide tubicole Lanice conchilega (Pallas, 1766) (polychète térébellidé) associé à la 
conchyliculture en Baie des Veys (Baie de Seine occidentale). Thèse de doctorat, Muséum National d'Histoire Naturelle, Paris. 186 pp.

Rosecchi, E., 1987. L'alimentation de Diplodus annularis, Diplodus sargus, Diplodus vulgaris et Sparus aurata (Pisces, Sparidae) dans le Golfe du Lion et les lagunes littorals. Revue des Travaux de l'Institut des Pêches Maritimes, 49: 125-141.

Rosecchi, E., Nouaze, Y., 1987. Comparaison de cinq indices alimentaires utilisés dans l'analyse des contenus stomacaux. Revue des Travaux de l'Institut des Pêches Maritimes, 49: 111-123.

Rossi, S.A., Sabates, A., Latasa, M., Reyes, E., 2006. Lipid biomarkers and trophic linkages between phytoplankton, zooplankton and anchovy (Engraulis encrasicolus) larvae in the NW Mediterranean. Journal of Plankton Research, 28(6): 551-562.

Roussel, E., Beaubrun, P., David, L., Di-Méglio, N., Airoldi, S., Panigada, S., Zanardelli, M., Notarbartolo di Sciara, G., 2000. Programme POSEIDON (1995 - 1998): Distributions des cétacés et des activités humaines en Méditerranée nord-occidentale. 104 pp.

Ruchonnet, D., Boutoute, M., Guinet, C., Mayzaud, P., 2006. Fatty acid composition of Mediterranean fin whale Balaenoptera physalus blubber with respect to body heterogeneity and trophic interaction. Marine Ecology-Progress Series, 311: 165-174.

Ruitton, S., Francour, P., Boudouresque, C. F., 2000. Relationships between algae, benthic herbivorous invertebrates and fishes in rocky sublittoral communities of a temperate sea (Mediterranean). Estuarine Coastal and Shelf Science, 50(2): 217-230.

Sabatés, A., Olivar, M.P., Salat, J., Palomera, I., Alemany, F., 2007. Physical and biological processes controlling the distribution of fish larvae in the NW Mediterranean. Progress in Oceanography, 74(2-3): 355-376.

Sacchi, J., 2008. Impact des techniques de pêche sur l'environnement en Méditerranée. Études et révues, General Fisheries Commission for the Mediterranean, 84: 1-82.

Sala, E., Boudouresque, C.F., 1997. The role of fishes in the organisation of a Mediterranean sublittoral community. I. Algal communities. Journal of Experimental Marine Biology and Ecology, 212: 25-44.

Sala, E., Boudouresque, C.F., Harmelin-Vivien, M., 1998. Fishing, trophic cascades, and the structure of algal assemblages: evaluation of an old but untested paradigm. Oikos, 82(3): 425-439.

Saiz, E., Calbet, A., Atienza, D., Alcaraz, M., 2007. Feeding and production of zooplankton in the Catalan Sea (NW Mediterranean). Progress in Oceanography, 74: 313-328. 
Sardà, F., 1998. Symptoms of overexploitation in the stock of the Norway lobster (Nephrops norvegicus) on the "Serola Bank" (Western Mediterranean Sea off Barcelona). Scientia Marina, 62 (3): 295-299.

Sánchez, F., Olaso, I., 2004. Effects of fisheries on the Cantabrian Sea shelf ecosystem. Ecological Modelling, Placing Fisheries in their Ecosystem Context, 172(2-4): 151-174.

Santic, M.I., Jardas, I., Pallaoro, A., 2003. Feeding habits of Mediterranean horse mackerel, Trachurus mediterraneus (Carangidae), in the central Adriatic Sea. Cybium, 27(4): 247253.

Santic, M., Jardas, I., Pallaoro, A., 2005. Feeding habits of horse mackerel, Trachurus trachurus (Linneaus, 1758), from the central Adriatic Sea. Journal of Applied Ichthyology, 21(2): 125-130.

Santic, M., Mikulandra, I., Pallaoro, A., Jardas, I., Staglicic, N., 2009. Diet of poor cod, Trisopterus minutus (Osteichthyes: Gadidae) from the eastern central Adriatic Sea. Cahiers de Biologie Marine, 50(2): 183-192.

Sever, T.M., Bayhan, B., Bilecenoglu, M., Mavili, S., 2006. Diet composition of the juvenile chub mackerel (Scomber japonicus) in the Aegean Sea (Izmir Bay, Turkey). Journal of Applied Ichthyology, 22(2): 145-148.

Shin, Y.-J., Cury, P., 2004. Using an individual-based model of the assemblages to study the response of size spectra to changes in fishing. Canadian Journal of Fisheries and Aquatic Sciences, 61: 414-431.

Steele, J. H., 2009. Assessment of some linear food web methods. Journal of Marine Systems, 76:186-194.

Stergiou, K.I., 1993. Abundance-depth relationship, condition factor and adaptive value of zooplanktophagy for red bandfish, Cepola macrophthalma. Journal of Fish Biology, 42(5): 645-660.

Stergiou, K.I., Karpouzi, V.S., 2002. Feeding habits and trophic levels of Mediterranean fish. Reviews in Fish Biology and Fisheries, 11(3): 217-254.

Stora, G., Bourcier, M., Arnoux, A., Gerino, M., Le Campion, J., Gilbert, F., Durbec, J.P., 1999. The deep-sea macrobenthos on the continental slope of the northwestern Mediterranean Sea: a quantitative approach. Deep-Sea Research Part I - Oceanographic Research Papers, 46(8): 1339-1368.

Strickland, J.D.H., 1966. Measuring the production of marine phytoplankton. Vol. 122. Fisheries Research Board of Canada, Ottawa, Canada.

Tanaka, T., Rassoulzadegan, F., 2002. Full-depth profile (0-2000 m) of bacteria, heterotrophic nanoflagellates and ciliates in the NW Mediterranean Sea: Vertical partitioning of 
microbial trophic structures. Deep-Sea Research Part II - Topical Studies in Oceanography, 49(11): 2093-2107.

Thezenas, S., 1993. Régime alimentaire du goéland leucophée Larus cachinnans michahellis, dans le basin Méditerranéen. Mémoire de l'Ecole Pratique des Hautes Etudes. 42 pp.

Trites, A., Christensen, V., Pauly, D., 1997. Competition between fisheries and marine mammals for prey and primary production in the Pacific Ocean. Journal of Northwest Atlantic Fishery Science, 22: 173-187.

Tsagarakis, K., Coll, M., Giannoulaki, M., Somarakis, S., Papaconstantinou, C., Machias, A., 2010. Food-web traits of the North Aegean Sea ecosystem (Eastern Mediterranean) and comparison with other Mediterranean ecosystems. Estuarine Coastal and Shelf Science, 88(2): 233-248.

Ulanowicz, R.E., 1986. Growth and development: ecosystem phenomenology. Springer Verlag, New York. 203 pp.

Ulanowicz, R.E., Norden, J.S., 1990. Symmetrical overhead in flow networks. International Journal of Systems Science, 21: 429-437.

Ulanowicz, R.E., Puccia, C.J., 1990. Mixed trophic impacts in ecosystems. Coenoses, 5: 7-16. Vadstein, O., 2009. Interactions in the planktonic food web. In Ecosystem Barents Sea, pp. 251-266. Ed. by Johnsen, G., Sakshaug, E., and Kovacs K. Tapir Academic Press, Trondheim, Norwey.

Vaqué, D., Blough, H.A., Duarte, C.M., 1997. Dynamics of ciliate abundance, biomass and community composition in an oligotrophic coastal environment (NW Mediterranean). Aquatic Microbial Ecology, 12:71-83.

Vaudo, G., 2002. Contribution à l'étude des pêcheries marines et lagunaires interactives du golfe du Lion. Thèse de doctorat, Université Aix-Marseille III. 173 pp.

Velsch, J.-P., 1997. Dynamique de population et migrations verticales de Meganyctiphanes norvegica (Crustacés: Euphausiacés) en Méditerranée Nord-Occidentale. Thèse de doctorat, Université Aix-Marseille 2, Marseille, France. 132 pp.

Walters, C., Christensen, V., Pauly, D., 1997. Structuring dynamic models of exploited ecosystems from trophic mass-balance assessments. Reviews in Fish Biology and Fisheries, 7: 139-172.

Walters, C., Pauly, D., Christensen, V., Kitchell, J. F., 2000. Representing density dependent consequences of life history strategies in aquatic ecosystems: EcoSim II. Ecosystems, 3(1): 70-83.

Whipple, S., Link, J.S., Garrison, L.P., Fogarty, M.J., 2000. Models of predation and fishing mortality in aquatic ecosystems. Fish and Fisheries, 1: 22-40. 
Wulff, F., Field, J.G., Mann, K.H., 1989. Network analysis in marine ecology. Methods and applications. Coastal and Estuarine Studies, vol. 32. Springer-Verlag, New York. 134 pp.

http://oceancolor.gsfc.nasa.gov

www.ecopath.org

www.fishbase.org 


\section{Figures captions}

Figure 1. Study area situated in the Gulf of Lions (north-western Mediterranean Sea).

Figure 2. Structure of the pelagic, demersal and benthic food web. The links between the different compartments show the trophic flows. Continous arrows indicate main flows and dotted arrows indicate less important flows.

Figure 3. Representation of coupling (flows of biomass between pelagic - demersal and benthic - demersal compartments) through consumption. Flows to detritus were not considered and flows to/from other groups not involved into coupling between compartments were not represented. Numbers between brakets represent groups numbers (cf. Table 1). Demersal fish play a highly important top down control in the system and in coupling processes. The arrows are proportional to the consumption trophic flows.

Figure 4. Lindeman spine of the Gulf of Lions's EwE model: flows between trophic levels (model based on R3 report). $\mathrm{P}=$ primary producers, $\mathrm{D}=$ detritus, $2-5=$ trophic levels $(\mathrm{TL})$.

Figure 5. Consumption of the biomass produced by the functional groups in the food web: a) consumption of all groups b) consumption of fish.

Figure 6. Graphic representation of the mixed trophic impact of each functional group on the other groups.

Figure 7. Relative total impact versus keystoneness $\left(\mathrm{KS}_{\mathrm{i}}\right)$ (Libralato et al., 2006) showing the role of species/groups in the ecosystem. The size of the circles is proportional to their biomass. Groups such as seabirds and dolphins with high keystoneness and low biomass were considered as keystone species, while groups with high relative total impact, keystone index and biomass such as Atlantic mackerel were considered as dominant species.

Figure 8. Composition of total annual landings in the Gulf of Lions in 2007-2008 (based on data from R3 report).

Figure 9. Graphic representation of the cumulate impact of the fishing gears on the Gulf of Lions' system induced by direct or cascade effect. The cumulate impact of a gear is the sum of its impacts on all model groups (excepting the other gears) and is based on the results from the MTI method. Excepting purse seine 12-24 m, all the gear had negative values of the total impact. 


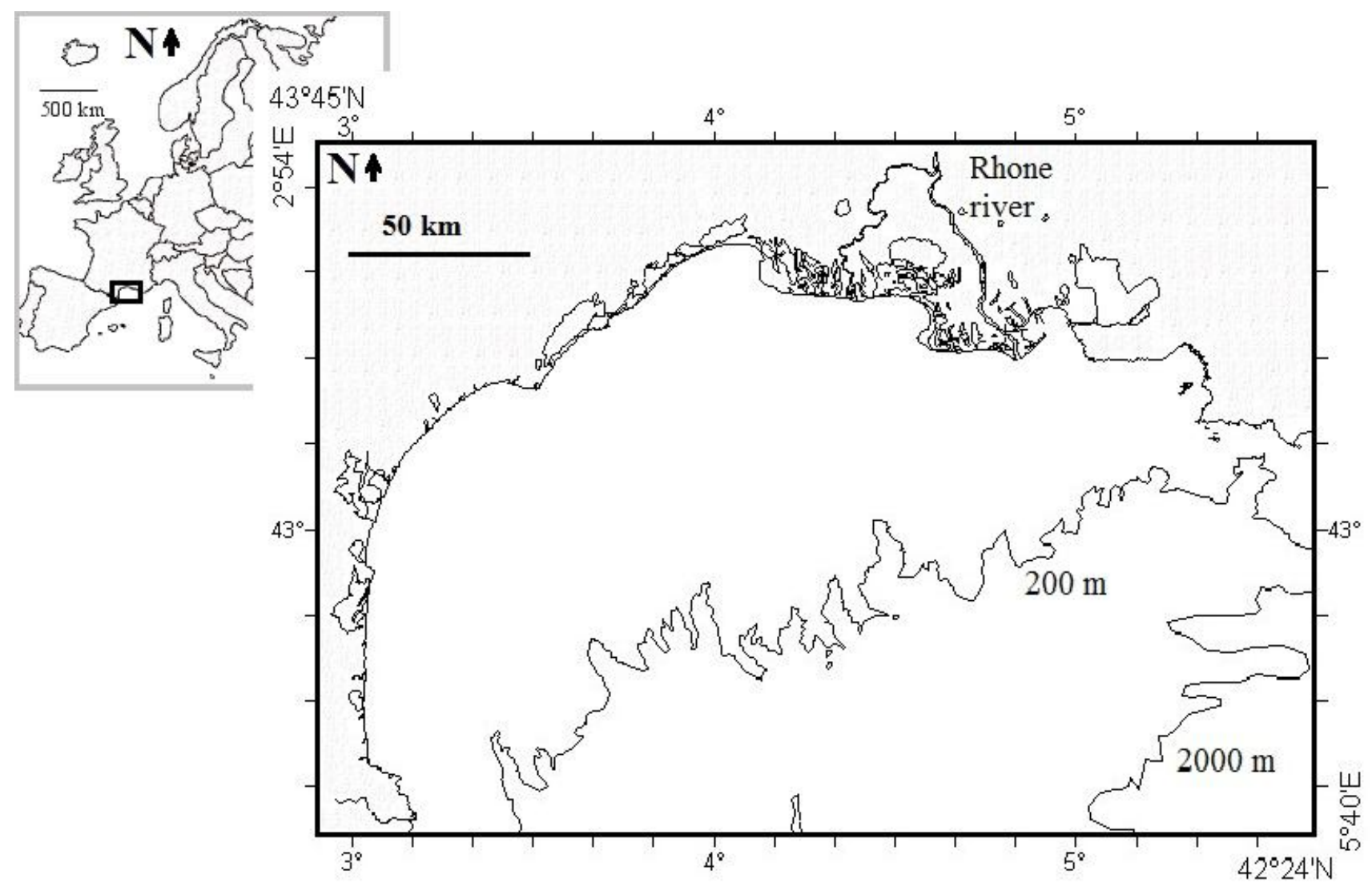

Figure 1. 


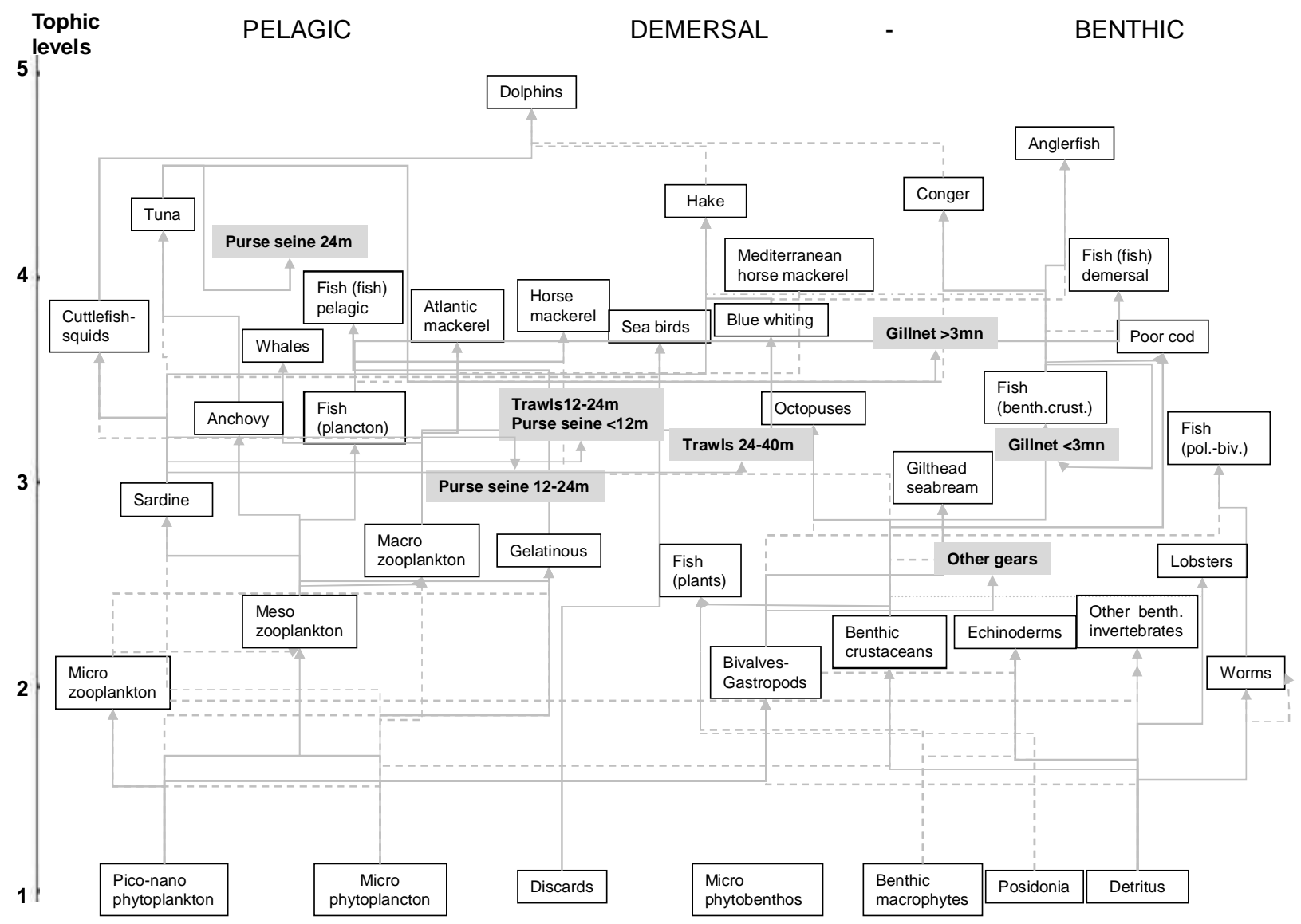

Figure 2.

You created this PDF from an application that is not licensed to print to novaPDF printer (http://www.novapdf.com) 


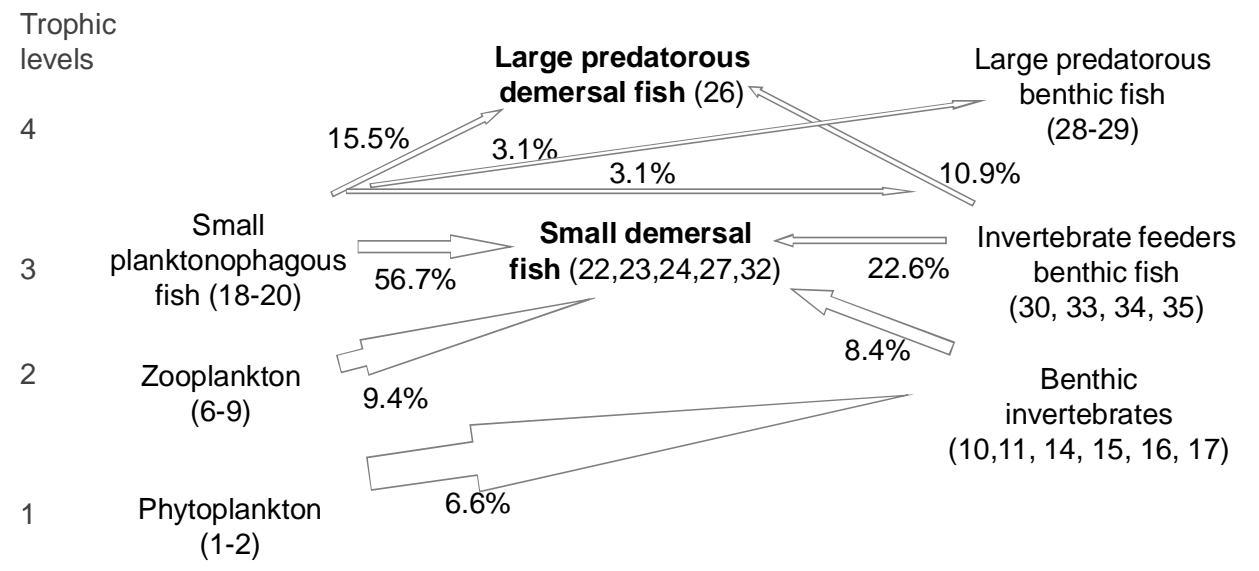

Figure 3.

You created this PDF from an application that is not licensed to print to novaPDF printer (http://www.novapdf.com) 


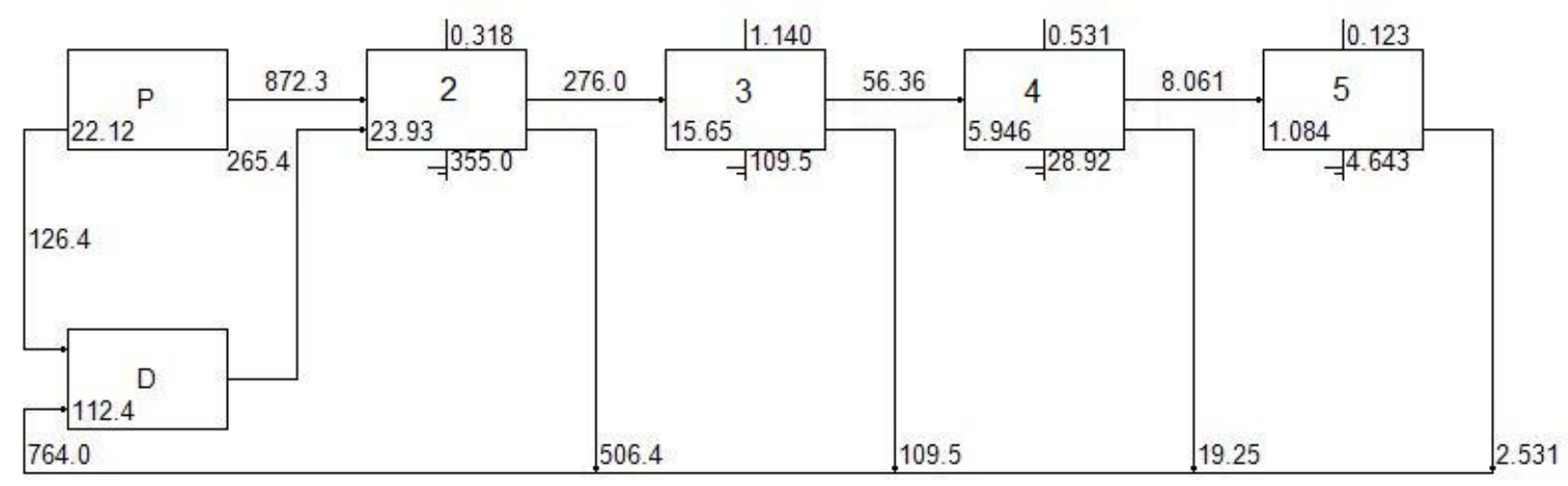

\begin{tabular}{|c|c|c|}
\hline \multirow[b]{2}{*}{ consumption } & \multicolumn{2}{|c|}{ lexports and catches } \\
\hline & & predation \\
\hline $\begin{array}{l}\text { flow to } \\
\text { detritus }\end{array}$ & fre & $\begin{array}{l}\text { flow to } \\
\text { detritus }\end{array}$ \\
\hline
\end{tabular}

Figure 4.

You created this PDF from an application that is not licensed to print to novaPDF printer (http://www.novapdf.com) 

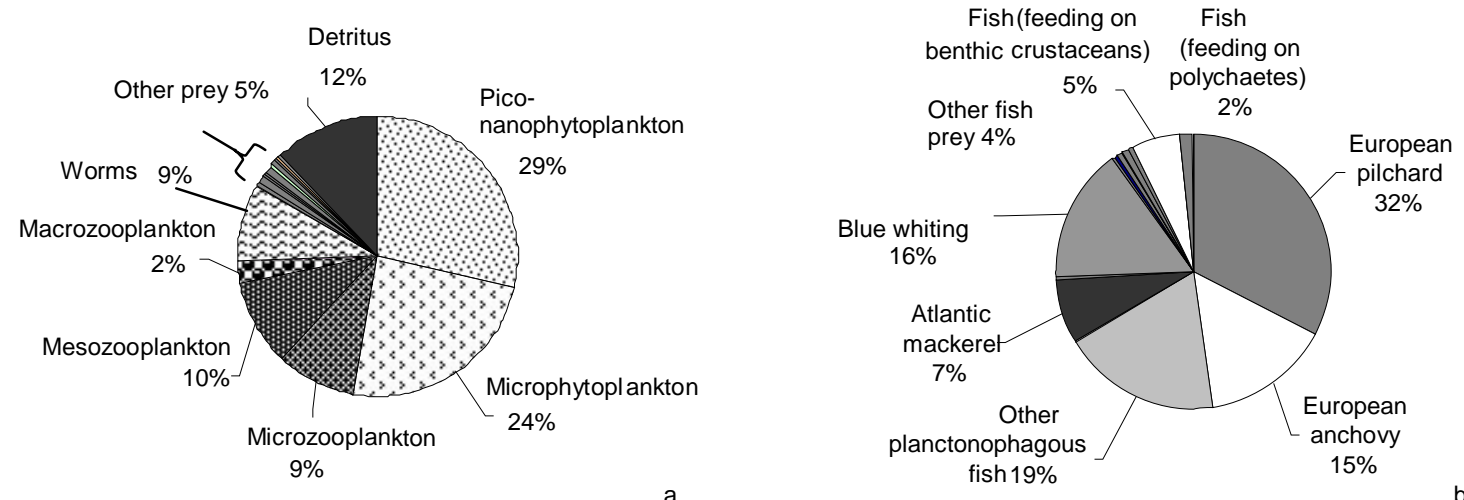

Figures 5a, 5b.

You created this PDF from an application that is not licensed to print to novaPDF printer (http://www.novapdf.com) 


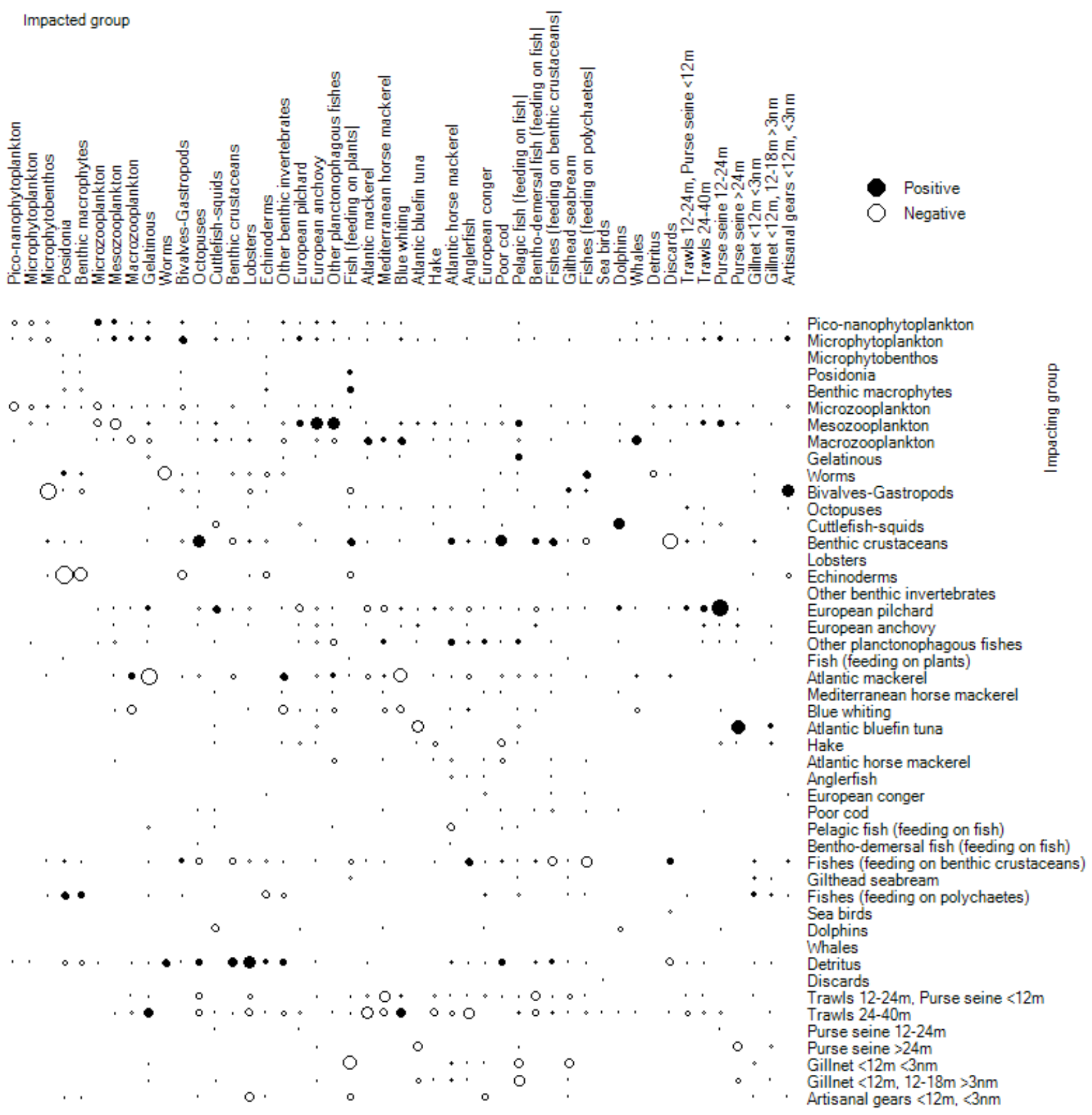

Figure 6.

You created this PDF from an application that is not licensed to print to novaPDF printer (http://www.novapdf.com) 


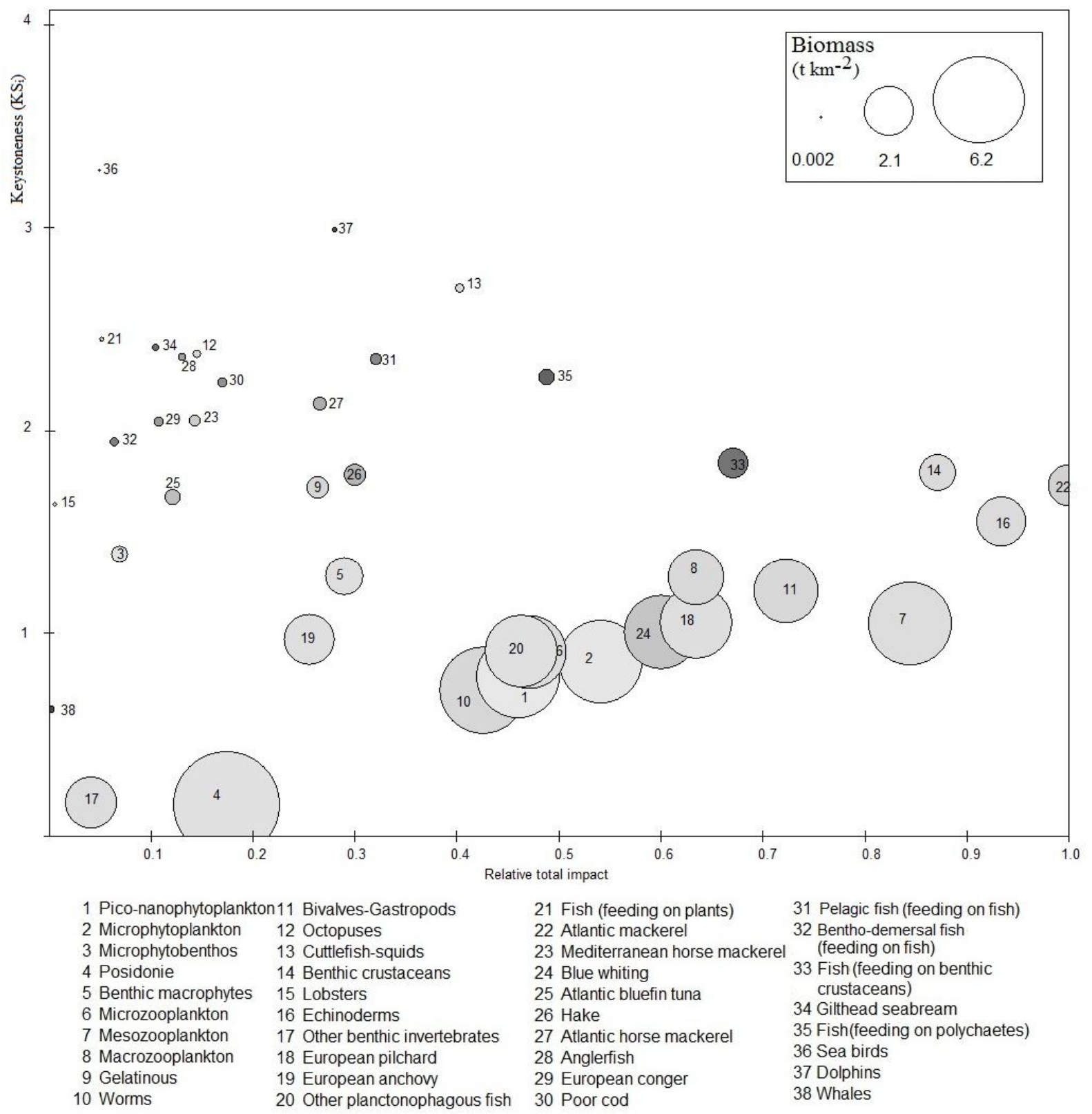

Figure 7.

You created this PDF from an application that is not licensed to print to novaPDF printer (http://www.novapdf.com) 


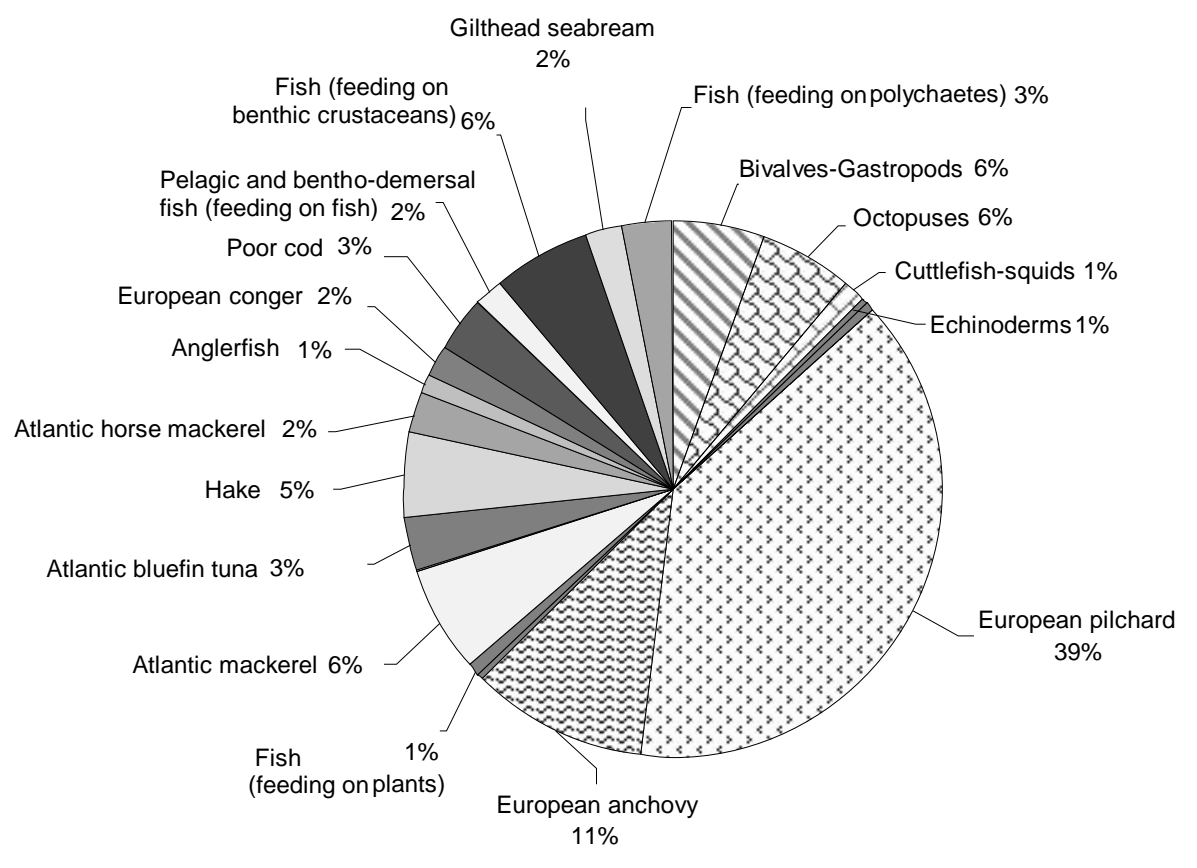

Figure 8.

You created this PDF from an application that is not licensed to print to novaPDF printer (http://www.novapdf.com) 


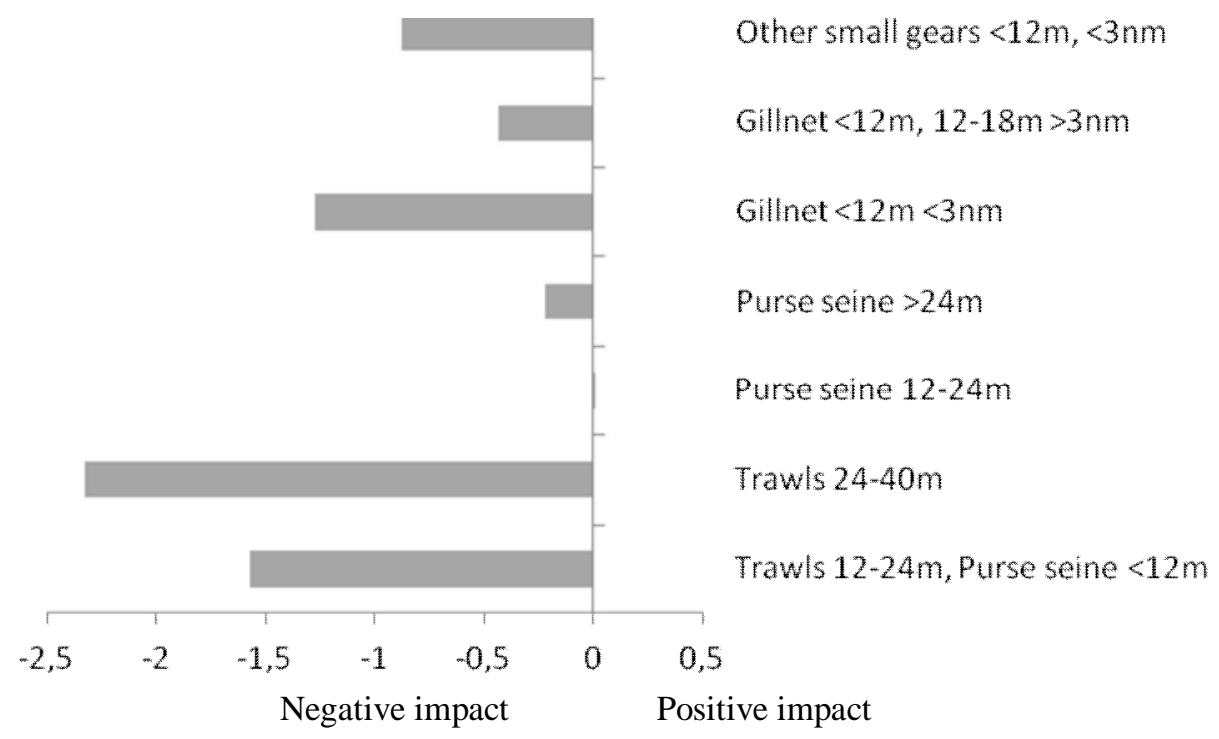

Figure 9. 
Table 1. Description of the functional groups of the Gulf of Lions' Ecopath model.

\begin{tabular}{|c|c|c|}
\hline \multicolumn{2}{|c|}{ Functional group } & \multirow{2}{*}{$\begin{array}{l}\text { Common and latin names of species/groups and their percentages } \\
\text { autotrophe bacteria, pico-eucaryotes (Synechococcus), autotrophe } \\
\text { nanophytoplancton (Mesodinium) }\end{array}$} \\
\hline 1 & Pico-nanophytoplankton & \\
\hline 2 & Microphytoplankton & diatoms, dinoflagellates \\
\hline 3 & Microphytobenthos & spp. \\
\hline 4 & Posidonia & Posidonia oceanica leaf (blade and sheath) \\
\hline 5 & $\begin{array}{l}\text { Benthic macrophytes and } \\
\text { epibionts }\end{array}$ & spp. \\
\hline 6 & Nano-microzooplankton & $\begin{array}{l}\text { ciliats, eggs and nauplii of copepods, small cladocerans, } \\
\text { pteropods, euphausids, mysids }\end{array}$ \\
\hline 7 & Mesozooplankton & $\begin{array}{l}\text { copepods, cladorerans, pteropods, euphausids, mysids, } \\
\text { amphipods, ostracods, fish and invertebrate eggs and larvaes }\end{array}$ \\
\hline 8 & Macrozooplankton & $\begin{array}{l}\text { krill, fish and invertebrate eggs and larvaes, pteropods, } \\
\text { euphausids, mysids, amphipods }\end{array}$ \\
\hline 9 & Gelatinous zooplankton & $\begin{array}{l}\text { siphonophorae, tunicate (salpida, doliolida, appendicularia), } \\
\text { hydromedusae, ctenophora, chaetognatha }\end{array}$ \\
\hline 10 & Worms & nematods and annelids \\
\hline 11 & Bivalves and gastropods & spp. \\
\hline 12 & Octopuses & Octopus spp., Eledone cirrhosa, E. moschata \\
\hline 13 & Cuttlefish and squids & $\begin{array}{l}\text { Sepia spp., Sepietta spp., Sepiola spp., Ilex coindettii, Loligo } \\
\text { spp., Todarodes spp., Allotheuthis spp., Histioteuthis spp. }\end{array}$ \\
\hline 14 & $\begin{array}{l}\text { Suprabenthic and benthic } \\
\text { crustaceans }\end{array}$ & $\begin{array}{l}\text { mysids, amphipods, isopods, cumaceans, benthic copepods, } \\
\text { euphausids, pagurids, shrimps, brachyurids }\end{array}$ \\
\hline 15 & Lobsters & Nephrops norvegicus, Palinurus spp., Homarus vulgaris \\
\hline 16 & Echinoderms & echinids, asterids, ophiurids, crinoids, holothurians \\
\hline 17 & Other benthic invertebrates & cnidarians, sponges, tunicats, siponcles, etc \\
\hline 18 & European pilchard & Sardina pilchardus (W., 1972) \\
\hline 19 & European anchovy & Engraulis encrasicholus (L., 1758) \\
\hline 20 & $\begin{array}{l}\text { Other planctonophagous } \\
\text { Fish }\end{array}$ & $\begin{array}{l}28 \% \text { round sardinella- Sardinella aurita } \text { V., } 1847 ; 20 \% \text { European } \\
\text { sprat- Sprattus sprattus (L., 1758); } 50 \% \text { picarel- Spicara spp.; } \\
2 \% \text { red bandfish- Cepola macrophthalma (L., 1758); <1\% big- } \\
\text { scale sand smelt- Atherina boyeri R., } 1810\end{array}$ \\
\hline 21 & Fish (feeding on plants) & $\begin{array}{l}90 \% \text { bogue- Boops boops (L., 1758); 10\% salema- Sarpa salpa } \\
\text { (L., 1758) }\end{array}$ \\
\hline 22 & Atlantic mackerel & Scomber scombrus L., 1758 \\
\hline 23 & Mediterranean horse mackerel & Trachurus mediterraneus (S., 1868) \\
\hline 24 & Blue whiting & Micromesistius poutassou (R., 1827) \\
\hline 25 & Atlantic bluefin tuna & Thunnus thynnus (L., 1758) \\
\hline 26 & European hake & Merluccius merluccius (L., 1758) \\
\hline 27 & Atlantic horse mackerel & Trachurus trachurus (L., 1758) \\
\hline 28 & Anglerfish & 67\% Lophius budegassa S., 1807; 33\% L. piscatorius L., 1758 \\
\hline 29 & European conger & Conger conger $(\mathrm{L} ., 1758)$ \\
\hline 30 & Poor cod & Trisopterus minutus (L., 1758) \\
\hline 31 & Pelagic fish (feeding on fish) & $\begin{array}{l}72 \% \text { Chub mackerel- Scomber japonicus H., 1782; } 28 \% \\
\text { swordfish- Xiphias gladius L., } 1758\end{array}$ \\
\hline 32 & $\begin{array}{l}\text { Bentho-demersal fish } \\
\text { (feeding on fish) }\end{array}$ & $\begin{array}{l}\text { 44\% small-spotted catshark- Scyliorhinus canicula (L., 1758); } \\
43 \% \text { raies- Raja spp.; } 9 \% \text { East Atlantic red gurnard- Aspitrigla } \\
\text { cuculus (L., 1758); } 2 \% \text { megrim- Lepidorhombus whiffiagonis } \\
\text { (W., 1792); } 2 \% \text { brill- Scophtalmus rhombus (L., 1758) }\end{array}$ \\
\hline 33 & $\begin{array}{l}\text { Fish (feeding on benthic } \\
\text { crustaceans) }\end{array}$ & $\begin{array}{l}45 \% \text { European seabass- Dicentrarchus labrax (L., 1758); } 22 \% \\
\text { gurnards- Trigla spp., Lepidotrigla spp., Eutrigla gurnardus (L., }\end{array}$ \\
\hline
\end{tabular}


34 Gilthead seabream

35 Fish (feeding on polychaetes, bivalve and gastropods)

36 Sea birds

37 Dolphins

$\begin{array}{ll}38 & \text { Whales } \\ 39 & \text { Detritus } \\ 40 & \text { Discards }\end{array}$

1758); 10\% scorpion fish- Scorpaena spp., Helicolenus dactylopterus dactylopterus (D., 1809); 9\% red mullets- Mullus barbatus barbatus L., 1758, M. surmuletus L., 1758; 8\% axillary seabream- Pagellus acarne (R., 1827); $2 \%$ fourspotted megrimLepidorhombus boscii (R., 1810); 2\% greater forkbeard Phycis blennoides (B., 1768); $2 \%$ gobies- Gobius spp.; <1\% mulletsMugil spp., Liza spp.

Sparus aurata L., 1758

85\% soles- Solea spp.; 9\% common pandora- Pagellus erythrinus (L., 1758); 4\% striped seabream- Lithognathus mormyrus (L., 1758); $2 \%$ sars- Diplodus spp.; < 1\% Mediterranean rainbow wrasse- Coris julis (L., 1758) 90.9\% gulls- Larus michahellis; shearwaters : $6.4 \%$ Calonectris diomedea diomedea, $0.1 \%$ Puffinus yelkouan yelkouan, $0.5 \%$ P. yelkouan mauretanicus; $1.2 \%$ terns- Sterna hirundo; $0.9 \%$ Northern Gannet- Morus bassanus $12.4 \%$ bottlenose dolphin- Turpsios truncatus, $17.3 \%$ striped dolphin- Stenella coeruleoalba, 3.4\% Risso's dolphin- Grampus griseus; $5.1 \%$ sperm whale- Physeter macrocephalus; $61.8 \%$ pilot whale- Globicephala melas fin whale- Balaenoptera physalus and associated heterotrophe bacteria $20 \%$ of total landings of Sardina pilchardus, $60 \%$ of total landings of Trachurus spp. 
Table 2. Input parameters of the Gulf of Lions's Ecopath model by functional group: $\mathrm{B}_{\mathrm{i}}=$ initial estimated biomass, $\mathrm{P} / \mathrm{B}=$ production/biomass, $\mathrm{Q} / \mathrm{B}=$ consumption/biomass, $\mathrm{EE}=$ ecotrophic efficiency, $\mathrm{U} / \mathrm{Q}=$ unassimilated food/consumption.

\begin{tabular}{|c|c|c|c|c|c|c|c|}
\hline & Functional group & $\begin{array}{l}\mathrm{B}_{\mathrm{i}} \\
\text { (tons } \mathrm{km}^{-2} \text { ) }\end{array}$ & $\begin{array}{l}\text { P/B } \\
\left(\mathrm{y}^{-1}\right)\end{array}$ & $\begin{array}{l}\mathrm{Q} / \mathrm{B} \\
\left(\mathrm{y}^{-1}\right)\end{array}$ & $\mathrm{EE}$ & $\mathrm{U} / \mathrm{Q}$ & $\begin{array}{l}\text { Total landings } \\
\text { (R3 repport) }\end{array}$ \\
\hline 1 & Pico-nanophytoplankton & 5.70 & 97.29 & & & & \\
\hline 2 & Microphytoplankton & 5.70 & 84.29 & & & & \\
\hline 3 & Microphytobenthos & 0.21 & 4.82 & & & & \\
\hline 4 & Posidonie & 0.22 & 0.55 & & 0.10 & & \\
\hline 5 & Benthic macrophytes & 0.16 & 1.08 & & 0.75 & & \\
\hline 6 & Microzooplankton & 2.02 & 42.52 & 120.00 & 0.66 & 0.40 & \\
\hline 7 & Mesozooplankton & 2.04 & 39.00 & 80.00 & 0.66 & 0.40 & \\
\hline 8 & Macrozooplankton & 0.74 & 18.00 & 38.00 & 0.66 & 0.20 & \\
\hline 9 & Gelatinous & 0.04 & 18.00 & 38.00 & 0.20 & 0.20 & \\
\hline 10 & Worms & 6.18 & 5.61 & 30.00 & & 0.60 & \\
\hline 11 & Bivalves-Gastropods & 3.40 & 1.06 & 4.00 & & 0.40 & 0.104 \\
\hline 12 & Octopuses & 0.04 & 3.00 & 8.50 & & 0.20 & 0.116 \\
\hline 13 & Cuttlefish-squids & 0.02 & 3.20 & 9.10 & 0.95 & 0.20 & 0.024 \\
\hline 14 & Benthic crustaceans & 1.06 & 8.46 & 25.00 & & 0.30 & 0.004 \\
\hline 15 & Lobsters & 0.01 & 1.20 & 4.56 & & 0.20 & 0.005 \\
\hline 16 & Echinoderms & 0.34 & 0.26 & 2.47 & 0.43 & 0.30 & 0.011 \\
\hline 17 & Other benthic invertebrates & 2.16 & 1.02 & 4.00 & & 0.40 & \\
\hline 18 & European pilchard & 4.27 & 0.92 & 8.45 & & 0.30 & 0.884 \\
\hline 19 & European anchovy & 2.08 & 0.87 & 7.95 & & 0.30 & 0.202 \\
\hline 20 & Other planctonophagous fish & 0.28 & 0.84 & 9.95 & 0.50 & 0.30 & 0.005 \\
\hline 21 & Fish (feeding on plants) & 0.01 & 1.03 & 7.56 & & 0.30 & 0.013 \\
\hline 22 & Atlantic mackerel & 1.41 & 0.89 & 7.05 & & 0.20 & 0.122 \\
\hline 23 & Mediterranean horse mackerel & 0.10 & 0.97 & 6.91 & & 0.20 & 0.009 \\
\hline 24 & Blue whiting & 0.03 & 0.47 & 4.87 & 0.98 & 0.20 & 0.064 \\
\hline 25 & Atlantic bluefin tuna & 0.20 & 0.48 & 4.11 & & 0.20 & 0.111 \\
\hline 26 & Hake age & 0.38 & 0.61 & 2.15 & & 0.20 & 0.078 \\
\hline 27 & Atlantic horse mackerel & 0.08 & 1.18 & 6.91 & 0.84 & 0.20 & 0.024 \\
\hline 28 & Anglerfish & 0.04 & 0.69 & 5.70 & & 0.20 & 0.043 \\
\hline 29 & European conger & 0.01 & 0.91 & 4.15 & 0.86 & 0.20 & 0.061 \\
\hline 30 & Poor cod & 0.08 & 2.19 & 6.39 & & 0.20 & 0.032 \\
\hline 31 & Pelagic fish (feeding on fish) & 0.11 & 0.73 & 7.04 & & 0.20 & 0.002 \\
\hline 32 & Bentho-demersal fish (feeding on fish) & 0.06 & 0.63 & 3.61 & & 0.20 & 0.030 \\
\hline 33 & Fish (feeding on benthic crustaceans) & 0.17 & 2.06 & 6.22 & & 0.20 & 0.044 \\
\hline 34 & Gilthead seabream & 0.03 & 1.69 & 4.85 & & 0.20 & 0.058 \\
\hline 35 & Fish (feeding on polychaetes) & 0.08 & 2.10 & 7.79 & & 0.20 & 0.064 \\
\hline 36 & Sea birds & 0.002 & 0.60 & 66.00 & & 0.20 & \\
\hline 37 & Dolphins & 0.022 & 0.02 & 6.12 & & 0.20 & \\
\hline 38 & Whales & 0.044 & 0.01 & 4.04 & & 0.20 & \\
\hline 39 & Detritus & 112.2 & & & & & \\
\hline 40 & Discards & 0.17 & & & & & \\
\hline
\end{tabular}


Table 3. Diet composition matrix of the Gulf of Lions' EwE model

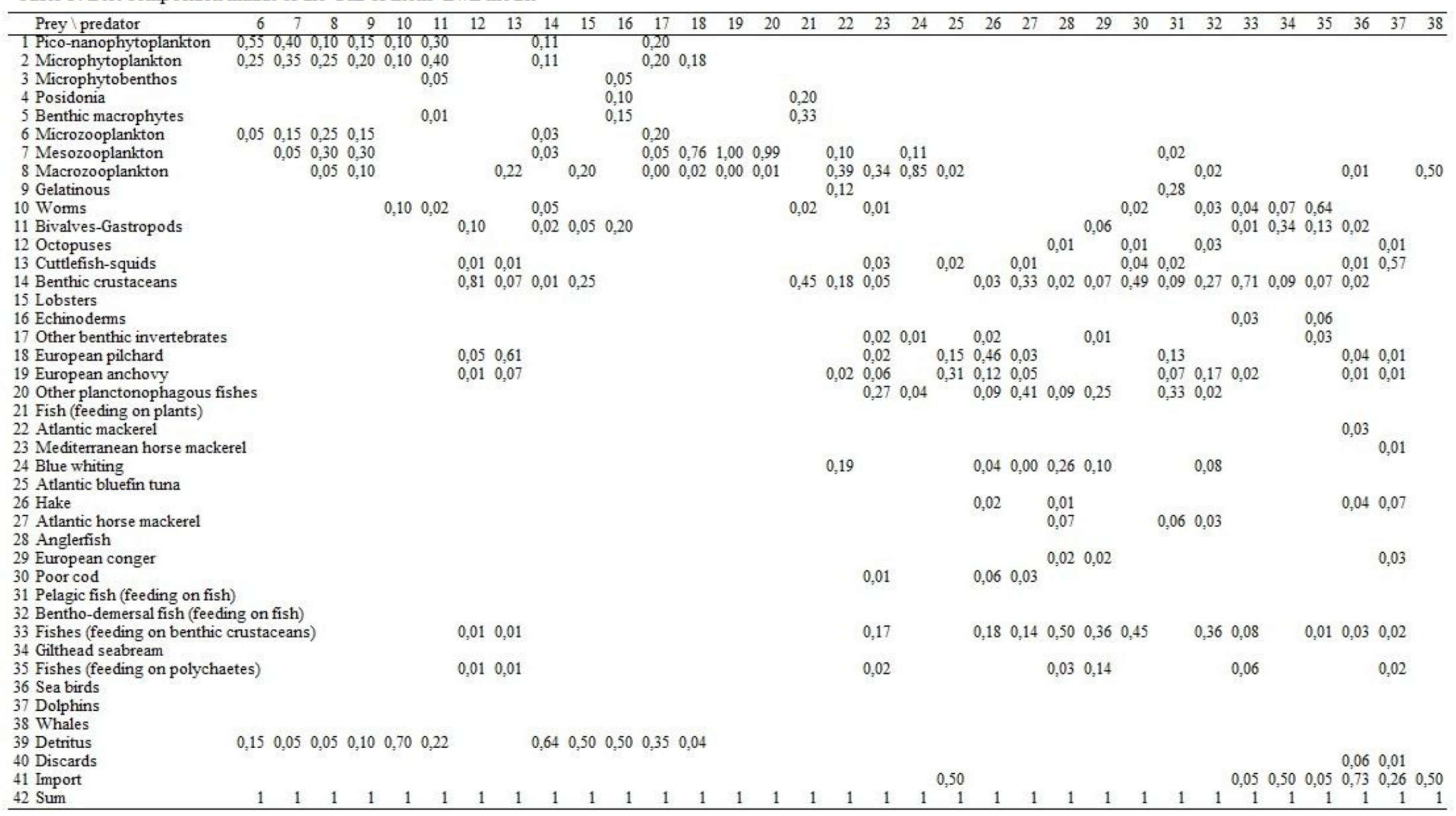


Table 4. Main output parameters of the Gulf of Lions' Ecopath model. In bold characters were indicated biomass parameters estimated by the model. $\mathrm{TL}=$ trophic level, $\mathrm{Bf}=$ final biomass $\left(\mathrm{t} \mathrm{km}^{-2}\right), \mathrm{EE}=$ ecotrophic efficiency, $\mathrm{F}=$ fishing mortality $\left(\mathrm{y}^{-1}\right), \mathrm{M} 2=$ predation mortality $\left(\mathrm{y}^{-1}\right), \mathrm{M} 0=$ natural mortality $\left(\mathrm{y}^{-1}\right), \mathrm{F} / \mathrm{Z}=$ exploitation rate, $\mathrm{Q}=$ consumtion $\left(\mathrm{km}^{-2} \mathrm{y}^{-1}\right), \mathrm{FD}=$ flow to detritus $\left(\mathrm{km}^{-2} \mathrm{y}^{-1}\right), \mathrm{P} / \mathrm{Q}=$ production / consumption, $\mathrm{NE}=$ net efficiency, OI=omnivory index.

\begin{tabular}{|c|c|c|c|c|c|c|c|c|c|c|c|c|c|}
\hline & Functional groups & TL & $\mathrm{Bf}$ & EE & $\mathrm{F}$ & M2 & M0 & $\mathrm{F} / \mathrm{Z}$ & $\mathrm{Q}$ & FD & $\mathrm{P} / \mathrm{Q}$ & $\mathrm{NE}$ & OI \\
\hline 1 & Pico-nanophytoplankton & 1.00 & 5.70 & 0.93 & 0.00 & 90.27 & 7.02 & 0.00 & & 30.02 & & & 0.00 \\
\hline 2 & Microphytoplankton & 1.00 & 5.70 & 0.74 & 0.00 & 62.35 & 21.94 & 0.00 & & 93.80 & & & 0.00 \\
\hline 3 & Microphytobenthos & 1.00 & 0.21 & 0.90 & 0.00 & 4.32 & 0.50 & 0.00 & & 0.11 & & & 0.00 \\
\hline 4 & Posidonie & 1.00 & 9.35 & 0.10 & 0.00 & 0.05 & 0.49 & 0.00 & & 2.30 & & & 0.00 \\
\hline 5 & Benthic macrophytes & 1.00 & 1.16 & 0.75 & 0.00 & 0.81 & 0.27 & 0.00 & & 0.16 & & & 0.00 \\
\hline 6 & Microzooplankton & 2.05 & 4.43 & 0.66 & 0.00 & 28.06 & 14.46 & 0.00 & 523.54 & 207.38 & 0.35 & 0.59 & 0.05 \\
\hline 7 & Mesozooplankton & 2.22 & 5.73 & 0.66 & 0.00 & 25.74 & 13.26 & 0.00 & 449.42 & 194.34 & 0.49 & 0.81 & 0.19 \\
\hline 8 & Macrozooplankton & 2.71 & 2.56 & 0.66 & 0.00 & 11.88 & 6.12 & 0.00 & 97.03 & 35.08 & 0.47 & 0.59 & 0.36 \\
\hline 9 & Gelatinous & 2.69 & 0.38 & 0.20 & 0.00 & 3.60 & 14.40 & 0.00 & 13.79 & 8.37 & 0.47 & 0.59 & 0.42 \\
\hline 10 & Worms & 2.11 & 6.18 & 0.62 & 0.00 & 3.46 & 2.15 & 0.00 & 185.28 & 124.46 & 0.19 & 0.47 & 0.11 \\
\hline 11 & Bivalves-Gastropods & 2.02 & 3.40 & 0.55 & 0.03 & 0.55 & 0.48 & 0.03 & 13.59 & 7.06 & 0.27 & 0.44 & 0.02 \\
\hline 12 & Octopuses & 3.23 & 0.05 & 0.93 & 2.50 & 0.30 & 0.20 & 0.83 & 0.4 & 0.09 & 0.35 & 0.44 & 0.09 \\
\hline 13 & Cuttlefis & 3.88 & 0.06 & 0.98 & 0.39 & 2.75 & 0.05 & 0.12 & 0.5 & 0.11 & 0.35 & 0.44 & 0.07 \\
\hline 14 & Benthic crustaceans & 2.16 & 1.06 & 0.74 & 0.00 & 6.23 & 2.22 & 0.00 & 26.4 & 10.29 & 0.34 & 0.48 & 0.15 \\
\hline 15 & Lobsters & 2.68 & 0.01 & 0.38 & 0.45 & 0.00 & 0.75 & 0.38 & 0.05 & 0.02 & 0.26 & 0.33 & 0.51 \\
\hline 16 & & 2.20 & 1.98 & 0.43 & 0.01 & 0.11 & 0.15 & 0.02 & 4.92 & 1.77 & 0.11 & 0.15 & 0.17 \\
\hline 17 & inve & 2.27 & 2.16 & 0.13 & 0.00 & 0.13 & 0.89 & 0.00 & 8.6 & 5.37 & 0.26 & 0.43 & 0.22 \\
\hline 18 & Europ & 2.96 & 4.27 & 0.48 & 0.21 & 0.2 & 0.48 & 0.22 & 36.03 & 12.86 & 0.11 & 0.16 & 0.27 \\
\hline 19 & $\begin{array}{l}\text { Europ } \\
\text { Other }\end{array}$ & 3.22 & 2.08 & 0.55 & 0.10 & 0.38 & 0.39 & 0.11 & 16.56 & 5.79 & 0.11 & 0.16 & 0.00 \\
\hline 20 & -phago & 3.22 & 4.30 & 0.50 & 0.00 & 0.42 & 0.42 & 0.00 & 40.62 & 14.63 & 0.08 & 0.12 & 0.00 \\
\hline 21 & ing on plants) & 2.54 & 0.01 & 0.91 & 0.93 & 0.01 & 0 & 0.91 & & 0.03 & 0.14 & 0.19 & 0.33 \\
\hline 22 & $\begin{array}{l}\text { Atlan } \\
\text { Medit }\end{array}$ & 3.75 & 1.41 & 0.10 & 0.09 & 0.00 & 0.80 & 0.10 & 9.94 & 3.11 & 0.13 & 0.16 & 0.26 \\
\hline 23 & macke & 4.01 & 0.10 & 0.10 & 0.09 & 0.01 & 0.87 & 0.10 & 0.67 & 0.22 & 0.14 & 0.18 & 0.15 \\
\hline 24 & Blue n & 3.67 & 4.50 & 0.98 & 0.00 & 0.46 & 0.0 & 0.00 & 21.98 & 4.43 & 0.10 & 0.12 & 0.04 \\
\hline 25 & Atlanti & 4.14 & 0.20 & 0.68 & 0.33 & 0.0 & 0.1 & 0.68 & 0.81 & 0.10 & 0.12 & 0.15 & 1.25 \\
\hline 26 & Hake & 4.14 & 0.38 & 0.63 & 0.30 & 0.0 & 0.2 & 0.48 & 0.8 & 0.25 & 0.28 & 0.36 & 0.11 \\
\hline 27 & Atlantic & 3.90 & 0.15 & 0.84 & 0.52 & $0.4^{\prime}$ & 0.1 & 0.44 & 0.9 & 0.23 & 0.17 & 0.21 & 0.29 \\
\hline 28 & Angle & 4.45 & 0.04 & 0.81 & 0.56 & 0.0 & 0.1 & 0.81 & 0.25 & 0.05 & 0.12 & 0.15 & 0.08 \\
\hline 29 & Europ & 4.16 & 0.07 & 0.86 & 0.58 & 0.20 & 0.1 & 0.64 & 0.31 & 0.07 & 0.22 & 0.27 & 0.21 \\
\hline 30 & & 3.76 & 0.08 & 0.88 & 0.81 & 1.11 & 0.26 & 0.37 & 0.48 & 0.12 & 0.34 & 0.43 & 0.38 \\
\hline 31 & $\begin{array}{l}\text { fish) } \\
\text { mersal fish }\end{array}$ & 3.98 & 0.11 & 0.02 & 0.02 & 0.00 & 0.72 & 0.02 & 0.82 & 0.23 & 0.10 & 0.13 & 0.19 \\
\hline 32 & $\begin{array}{l}\text { (feeding on } \\
\text { Fish (feedin }\end{array}$ & 3.98 & 0.06 & 0.85 & 0.54 & 0.00 & 0.10 & 0.85 & & 0.05 & 0.18 & 0.22 & 0.32 \\
\hline 33 & crustaceans) & 3.33 & 0.73 & 0.95 & 0.16 & 1.81 & 0.10 & 0.08 & 4.61 & 0.98 & 0.33 & 0.41 & 0.17 \\
\hline 34 & $\begin{array}{l}\text { Gilthead seabream } \\
\text { Fish (feeding }\end{array}$ & 3.06 & 0.03 & 0.84 & 1.42 & 0.00 & 0.27 & 0.84 & 0.15 & 0.02 & 0.35 & 0.44 & 0.53 \\
\hline 35 & & 3.1 & 0.20 & 0.96 & 0.29 & 1.7 & 0.0 & 0.14 & 1.5 & 0. & 0.27 & 0.34 & 0.03 \\
\hline 36 & Sea bi & 3.7 & 0.00 & 0.00 & 0.00 & 0.0 & 0.6 & 0.00 & 0.1 & 0.01 & 0.01 & 0.01 & 1.42 \\
\hline 37 & & 4.8 & 0.02 & 0.00 & 0.00 & 0.00 & 0.0 & 0.00 & 0.13 & 0.03 & 0.00 & 0.00 & 0.80 \\
\hline 38 & Whales & 3.71 & 0.04 & 0.00 & 0.00 & 0.00 & 0.01 & 0.00 & 0.18 & 0.02 & 0.00 & 0.00 & 0.92 \\
\hline 39 & Detritus & 1.00 & 112 & 0.35 & & & & & 872.16 & 0.00 & & 0.00 & 0.30 \\
\hline 40 & Discards & 1.00 & 0.17 & 0.36 & & & & & 0.00 & 0.11 & & 0.00 & 0.00 \\
\hline
\end{tabular}


Table 5. Ecological indicators related to community energetics, structure, flows and information theory. R3 model used data on landings from R3 observed landings report, while $\mathrm{H}$ model used data from auction sales database. In bold characters were indicated the differences between the results of the two models.

\begin{tabular}{|c|c|c|c|}
\hline Statistics and flows & $\begin{array}{l}\text { Value } \\
\text { R3 model }\end{array}$ & $\begin{array}{l}\text { Value } \\
\text { H model }\end{array}$ & Units \\
\hline Sum of all consumption & 1480.1 & 1480.1 & tons $\mathrm{km}^{-2} \mathrm{y}^{-1}$ \\
\hline Sum of all exports & 251.7 & 251.7 & tons $\mathrm{km}^{-2} \mathrm{y}^{-1}$ \\
\hline Sum of all respiratory flows & 498.7 & 498.7 & tons $\mathrm{km}^{-2} \mathrm{y}^{-1}$ \\
\hline Sum of all flows into detritus & 764.6 .3 & 764.6 .3 & tons $\mathrm{km}^{-2} \mathrm{y}^{-1}$ \\
\hline Total system throughput & 2995.0 & 2995.0 & tons $\mathrm{km}^{-2} \mathrm{y}^{-1}$ \\
\hline Sum of all production & 1572.8 & 1572.8 & tons $\mathrm{km}^{-2} \mathrm{y}^{-1}$ \\
\hline Mean trophic level of the catch & 3.24 & 3.35 & \\
\hline Gross efficiency (catch/net p.p.) & 0.002 & 0.001 & \\
\hline Calculated total net primary production & 1042.4 & 1042.4 & tons $\mathrm{km}^{-2} \mathrm{y}^{-1}$ \\
\hline Total primary production/total respiration & 2.09 & 2.09 & \\
\hline Net system production & 543.7 & 543.7 & tons $\mathrm{km}^{-2} \mathrm{y}^{-1}$ \\
\hline Total primary production/total biomass & 15.1 & 15.1 & \\
\hline Total biomass/total throughput & 0.023 & 0.023 & \\
\hline Total biomass (excluding detritus) & 68.9 & 68.9 & $\mathrm{t} \mathrm{km}^{-2}$ \\
\hline $\begin{array}{l}\text { Primary production required to sustain fishery/ } \\
\text { total primary production }\end{array}$ & 13.58 & 10.28 & $\%$ \\
\hline Total transfer efficiency & 19.70 & 19.70 & $\%$ \\
\hline Total catches & 2.131 & 1.274 & \\
\hline Connectance Index & 0.150 & 0.150 & \\
\hline Ecopath Pedigree index $(0-1)$ & 0.67 & 0.67 & \\
\hline \multicolumn{4}{|l|}{ Network flow indices } \\
\hline Throughput cycled (excluding detritus) & 73.52 & 73.52 & tons $\mathrm{km}^{-2} \mathrm{y}^{-1}$ \\
\hline Predatory cycling index & 4.29 & 4.29 & $\%$ of throughput without detritus \\
\hline Throughput cycled (including detritus) & 355.6 & 355.6 & tons $\mathrm{km}^{-2} \mathrm{y}^{-1}$ \\
\hline Finn's cycling index & 11.87 & 11.87 & $\%$ of total throughput \\
\hline Finn's mean path length & 3.99 & 3.99 & \\
\hline System Omnivory Index & 0.21 & 0.21 & \\
\hline \multicolumn{4}{|l|}{ Information indices } \\
\hline Ascendency & 17.4 & 17.4 & $\%$ \\
\hline Overhead & 82.6 & 82.6 & $\%$ \\
\hline Capacity (total) & 13809 & 13809 & flowbits \\
\hline
\end{tabular}


Appendix 1. Input data and references by functional group for the Gulf of Lions' EwE model. $\mathrm{P} / \mathrm{B}=$ production/biomass ratio $\left(\mathrm{y}^{-1}\right), \mathrm{Q} / \mathrm{B}=$ consumption/biomass ratio $\left(\mathrm{y}^{-1}\right), \mathrm{U} / \mathrm{B}=$ unassimilated food, $\mathrm{EE}=$ ecotrophic efficiency.

Functional group Sources and references

1. Pico-nanophytoplankton

Biomass http://oceancolor.gsfc.nasa.gov; 50\% microphytoplankton and 50\% pico-nanophytoplankton estimated by Lefevre et al., 1997; Rossi et al., 2006; Harmelin et al., 2008; Marty et al., 2008; Christaki et al., 2009;

P/B Lefevre et al., 1997; Gaudy et al., 2003; http://oceancolor.gsfc.nasa.gov;

2. Microphytoplankton

Biomass http://oceancolor.gsfc.nasa.gov; $50 \%$ microphytoplankton and 50\% pico-nanophytoplankton estimated by Lefevre et al., 1997; Rossi et al., 2006; Harmelin et al., 2008; Marty et al., 2008; Christachi et al., 2009;

P/B Lefevre et al., 1997; Gaudy et al., 2003; http://oceancolor.gsfc.nasa.gov;

3. Microphytobenthos

Biomass $\quad$ Plante-Cuny and Bodoy, 1987; Riaux-Gobin et al., 1998;

$\mathrm{P} / \mathrm{B}$

Plante-Cuny and Bodoy, 1987;

4. Posidonie

P/B Pergent-Martini et al., 1994; Pergent et al., 1997;

EE Pergent et al., 1997; Romero, 2004; Boudouresque et al., 2006;

5. Benthic macrophytes

$\mathrm{P} / \mathrm{B}$

McClanahan et Sala, 1997; Sala and Boudouresque, 1997;

$\mathrm{EE}$

Boudouresque (pers. comm.);

6. Nanomicrozooplankton

Biomass

Vaqué et al., 1997; Gaudy et al., 2003; Christaki et al., 2009; Banaru et al., pers comm.;

$\mathrm{P} / \mathrm{B}$

Plounevez and Champalbert, 2000; Gaudy et al., 2003;

$\mathrm{Q} / \mathrm{B}$

Plounevez and Champalbert, 2000; Gaudy et al., 2003;

$\mathrm{U} / \mathrm{B}$

Pinnegar, 2000;

Christensen and Pauly, 1991;

Trophic data Champalbert, 1996 Christaki et al., 2009; Decembrini et al., 2009; Banaru et al., pers. comm.;

7. Mesozooplankton Furnestin, 1960; Razouls and Kouwenberg, 1993; Plounevez and Champalbert, 2000; Gaudy et al., 2003; Banaru et al., pers. comm.;

Biomass Plounevez and Champalbert, 2000; Gaudy et al., 2003;

P/B Plounevez and Champalbert, 2000; Gaudy et al., 2003;

Q/B Pinnegar, 2000;

U/B Christensen and Pauly, 1991;

Trophic data Champalbert, 1996; Saiz et al., 2007; Christaki et al., 2009; Decembrini et al., 2009;

Banaru et al., pers. comm.;

8. $\quad$ Furnestin, 1960; Razouls and Kouwenberg, 1993; Velsch, 1997;

Macrozooplankton

Biomass

Boucher and Thiriot, 1972; Kulka and Corey, 1982; Velsch, 1997; Cartes et al., 2008;

$\mathrm{P} / \mathrm{B}$

Labat and Cuzin-Roudy, 1996; Velsch, 1997;

$\mathrm{Q} / \mathrm{B}$

Pinnegar, 2000;

$\mathrm{U} / \mathrm{B}$

Christensen and Pauly, 1991;

Trophic data

9. Gelatinous zooplankton

Bamstedt and Karlson, 1998; Sabatés et al., 2007; Saiz et al., 2007; Morote et al., 2008;

Eiane and Tande, 2009; Vadstein, 2009; Banaru et al., pers. comm.;

Biomass

Boucher and Thiriot, 1972; Bertrand et al., 1998; Cartes et al., 2008; French Mediterranean bottom trawl surveys - IFREMER database MEDITS (1994-2009);

$\mathrm{P} / \mathrm{B}$

Pinnegar, 2000; Coll et al., 2006, 2007;

$\mathrm{Q} / \mathrm{B}$

Pinnegar, 2000; Coll et al., 2006, 2007; 
Trophic data

10. Worms

Biomass

$\mathrm{P} / \mathrm{B}$

$\mathrm{Q} / \mathrm{B}$

$\mathrm{U} / \mathrm{B}$

Trophic data

11. Bivalves and gastropods

De Bovée et al., 1990; Ratsimbazafy et al., 1994; Stora et al., 1999; Labrune et al., 2007; Hermand et al., 2008; Sorbe, pers. comm.; Ropert, 1999; Sanchez and Olaso, 2004;

Pinnegar, 2000;

Christensen and Pauly, 1991;

Bozzano et Sarda, 2002; Darnaude et al., 2004a, b; Boudouresque et al., 2006;

Carlier et al., 2007; Banaru, 2008;
Biomass

$\mathrm{P} / \mathrm{B}$

$\mathrm{Q} / \mathrm{B}$

$\mathrm{U} / \mathrm{B}$

Trophic data

12. Octopuses

Biomass (meanmaximum)

$\mathrm{P} / \mathrm{B}$

$\mathrm{Q} / \mathrm{B}$

$\mathrm{U} / \mathrm{B}$

Trophic data

De Bovée et al., 1990; Stora et al., 1999; Labrune et al., 2007; Hermand et al., 2008;

Sorbe, pers. comm.;

Dauvin, 1985; Pinnegar, 2000;

Pinnegar, 2000; Coll et al., 2006, 2007;

Christensen and Pauly, 1991;

Sala et al., 1998; Ruitton et al., 2000; Bozzano et Sarda, 2002; Darnaude et al., 2004a, b; Boudouresque et al., 2006; Carlier et al., 2007; Sala and Boudouresque, 1997; Banaru, 2008; Cartes et al., 2008;

Bertrand et al., 1998; French Mediterranean bottom trawl surveys - IFREMER database MEDITS (1994-2009);

Sanchez and Olaso, 2004;

Pinnegar, 2000; Coll et al., 2006, 2007;

Christensen and Pauly, 1991;

Dieng et al., 2000;

13. Cuttlefish and squids

Biomass (mean- $\quad$ Bertrand et al., 1998; French Mediterranean bottom trawl surveys - IFREMER database maximum)

$\mathrm{P} / \mathrm{B}$ MEDITS (1994-2009);

Sanchez and Olaso, 2004;

$\mathrm{Q} / \mathrm{B}$

Sanchez and Olaso, 2004; Coll et al., 2006;

$\mathrm{U} / \mathrm{B}$

Christensen and Pauly, 1991;

Trophic data

Coelho et al., 1997; Alves et al., 2006;

14. Suprabenthic and benthic crustaceans

Biomass

$\mathrm{P} / \mathrm{B}$

$\mathrm{Q} / \mathrm{B}$

$\mathrm{U} / \mathrm{B}$

Trophic data

15. Lobsters

Biomass (meanmaximum)

$\mathrm{P} / \mathrm{B}$

$\mathrm{Q} / \mathrm{B}$

$\mathrm{U} / \mathrm{B}$

Trophic data

16. Echinoderms

Biomass
De Bovée et al., 1990; Stora et al., 1999; Labrune et al., 2007; Hermand et al., 2008;

Sorbe, pers. comm.;

Coll et al., 2006, 2007; Cartes and Sorbe, 1999;

Maynou and Cartes, 1998; Sanchez and Olaso, 2004;

Christensen and Pauly, 1991;

Cartes, 1998; Sala et al., 1998; Bozzano et Sarda, 2002; Darnaude et al.,

2004a, b; Boudouresque et al., 2006; Carlier et al., 2007; Banaru, 2008; Cartes et al., 2008;

Bertrand et al., 1998; French Mediterranean bottom trawl surveys - IFREMER database MEDITS (1994-2009);

Coll et al., 2006;

Coll et al., 2006, 2007;

Christensen and Pauly, 1991;

Sala et al., 1998; Ruitton et al., 2000; Bozzano et Sarda, 2002; Darnaude et al., 2004a, b; Boudouresque et al., 2006; Carlier et al., 2007; Banaru, 2008;

Cartes et al., 2008;

De Bovée et al., 1990; Stora et al., 1999; Labrune et al., 2007; Hermand et al., 2008; 
Sorbe, pers. comm.;

P/B Pinnegar, 2000;

Q/B Pinnegar, 2000;

U/B Christensen and Pauly, 1991;

Trophic data Sala et al., 1998; Ruitton et al., 2000; Bozzano et Sarda, 2002; Darnaude et al., 2004a, b; Boudouresque et al., 2006; Carlier et al., 2007; Sala and Boudouresque., 1997; Banaru, 2008;

Cartes et al., 2008;

17. Other benthic invertebrates

Biomass De Bovée et al., 1990; Stora et al., 1999; Labrune et al., 2007; Hermand et al., 2008;

Sorbe, pers. comm.;

P/B Coll et al., 2006, 2007;

Q/B Sanchez and Olaso, 2004; Coll et al., 2006;

U/B Christensen and Pauly, 1991;

Trophic data Sala et al., 1998; Ruitton et al., 2000; Bozzano and Sarda, 2002; Darnaude et al., 2004a, b; Boudouresque et al., 2006; Carlier et al., 2007; Banaru, 2008;

Cartes et al., 2008;

18. European pilchard

Biomass (mean- $\quad$ French Mediterranean pelagic acoustic surveys - IFREMER database PELMED (1993-2009); maximum)

$\mathrm{P} / \mathrm{B}$

Farrugio et al., 1991; Christensen et al., 2005; Roos, pers.comm. - GFCM;

$\mathrm{Q} / \mathrm{B}$

Farrugio et al., 1991; Palomares and Pauly, 1998; www.fishbase.org;

$\mathrm{U} / \mathrm{B}$

Christensen and Pauly, 1991;

Trophic data

Lee, 1961; Garrido et al., 2008;

Landings

FIS "Fisheries Information System"- IFREMER data on landings from auction sales Database (2002-2009); Demaneche et al., 2009 (landings 2007-2008);

19. European anchovy

Biomass (mean- $\quad$ French Mediterranean pelagic acoustic surveys - IFREMER database PELMED (1993-2009); maximum)

$\mathrm{P} / \mathrm{B}$

Campillo, 1992; Christensen et al., 2005; Roos, pers.comm. - GFCM;

$\mathrm{Q} / \mathrm{B}$

Campillo, 1992; Palomares and Pauly, 1998; www.fishbase.org;

$\mathrm{U} / \mathrm{B}$

Christensen and Pauly, 1991;

Trophic data

Plounevez and Champalbert, 2000;

Landings

FIS "Fisheries Information System"- IFREMER data on landings from auction sales

20. Other planctonophagous fish

Database (2002-2009); Demaneche et al., 2009 (landings 2007-2008);

Biomass (mean- $\quad$ French Mediterranean pelagic acoustic surveys - IFREMER database PELMED (1993-2009); maximum)

French Mediterranean bottom trawl surveys - IFREMER database MEDITS (1994-2009);

Bertrand et al., 1998;

$\mathrm{P} / \mathrm{B}$

Farrugio et al., 1991; Avsar, 1995; Christensen et al., 2005; GFCM, 2010;

$\mathrm{Q} / \mathrm{B}$

Farrugio et al., 1991; Avsar, 1995; www.fishbase.org;

$\mathrm{U} / \mathrm{B}$

Christensen and Pauly, 1991;

Trophic data

Bell and Harmelin, 1983; Danilova, 1991; Stergiou, 1993; Oven et al., 1997; Bowman et al., 2000;

Landings

21. Fish (feeding on plants)

FIS "Fisheries Information System"- IFREMER data on landings from auction sales Database (2002-2009);

Biomass (mean- $\quad$ French Mediterranean bottom trawl surveys - IFREMER database MEDITS (1994-2009); maximum) Bertrand et al., 1998;

$\mathrm{P} / \mathrm{B}$

Campillo, 1992; Christensen et al., 2005; www.fishbase.org;

$\mathrm{Q} / \mathrm{B}$

Campillo, 1992; Palomares and Pauly, 1998; www.fishbase.org;

$\mathrm{U} / \mathrm{B}$

Trophic data

Christensen and Pauly, 1991;

Landings

Bell and Harmelin, 1983; Pergent et al., 1994; Rico-Raimondino, 1995; Havelange et al., 1997;

FIS "Fisheries Information System"- IFREMER data on landings from auction sales Database (2002-2009); Demaneche et al., 2009 (landings 2007-2008); 
22. Atlantic mackerel

Biomass (mean- $\quad$ French Mediterranean pelagic acoustic surveys - IFREMER database PELMED (1993-2009); maximum)

$\mathrm{P} / \mathrm{B}$

Campillo, 1992; Christensen et al., 2005;

$\mathrm{Q} / \mathrm{B}$

Campillo, 1992; Palomares and Pauly, 1998; www.fishbase.org;

$\mathrm{U} / \mathrm{B}$

Christensen and Pauly, 1991;

Trophic data

Olaso et al., 2005;

Landings

FIS "Fisheries Information System"- IFREMER data on landings from auction sales

Database (2002-2009); Demaneche et al., 2009 (landings 2007-2008);

23. Mediterranean horse mackerel

Biomass (mean- $\quad$ French Mediterranean bottom trawl surveys - IFREMER database MEDITS (1994-2009);

maximum)

Bertrand et al., 1998;

$\mathrm{P} / \mathrm{B}$

Campillo, 1992; Christensen et al., 2005;

$\mathrm{Q} / \mathrm{B}$

Campillo, 1992; Palomares and Pauly, 1998; www.fishbase.org;

$\mathrm{U} / \mathrm{B}$

Christensen and Pauly, 1991;

Trophic data

Santic et al., 2003;

Landings

FIS "Fisheries Information System"- IFREMER data on landings from auction sales

24. Blue whiting

Database (2002-2009); Demaneche et al., 2009 (landings 2007-2008);

Biomass (mean-

maximum)

French Mediterranean bottom trawl surveys - IFREMER database MEDITS (1994-2009);

$\mathrm{P} / \mathrm{B}$

Bertrand et al., 1998;

Campillo, 1992; Christensen et al., 2005;

$\mathrm{Q} / \mathrm{B}$

Campillo, 1992; Palomares and Pauly, 1998; www.fishbase.org;

$\mathrm{U} / \mathrm{B}$

Christensen and Pauly, 1991;

Trophic data

Geistdoerfer, 1983;

Landings

25. Atlantic bluefin tuna

FIS "Fisheries Information System"- IFREMER data on landings from auction sales Database (2002-2009);

Biomass (mean) J.-M. Fromentin, pers. comm. estimated from VPA and aerial surveys

$\mathrm{P} / \mathrm{B}$

Campillo, 1992; Christensen et al., 2005;

$\mathrm{Q} / \mathrm{B}$

Campillo, 1992; Palomares and Pauly, 1998; www.fishbase.org;

U/B

Christensen and Pauly, 1991;

Trophic data

Contino, 2004; Bearzi et al., 2006; fishermen from the Gulf of Lions, pers. comm.;

Landings

J.-M. Fromentin, pers. comm.;

26. European hake

Biomass

Annual mean biomass (1998-2008) estimated by virtual population analysis (GFCM);

$\mathrm{P} / \mathrm{B}$

Christensen et al., 2005; Mellon et al., 2009; virtual population analysis parameters

$\mathrm{Q} / \mathrm{B}$

Campillo, 1992; Palomares and Pauly, 1998; virtual population analysis parameters;

U/B

Christensen and Pauly, 1991;

Trophic data

Mellon et al., in prep.;

Landings

27. Atlantic horse mackerel

Annual mean landings database (1998-2008) from French and Spanish sources used by GFCM for virtual population analysis;

Biomass (mean- $\quad$ French Mediterranean pelagic acoustic surveys - IFREMER database PELMED (1993-2009); maximum)

$\mathrm{P} / \mathrm{B}$

Campillo, 1992; Christensen et al., 2005;

$\mathrm{Q} / \mathrm{B}$

Campillo, 1992; Palomares and Pauly, 1998; www.fishbase.org;

$\mathrm{U} / \mathrm{B}$

Christensen and Pauly, 1991;

Trophic data

Santic et al., 2005;

Landings

FIS "Fisheries Information System"- IFREMER data on landings from auction sales

Database (2002-2009); Demaneche et al., 2009 (landings 2007-2008); 


\section{Anglerfish}

Biomass (meanmaximum)

$\mathrm{P} / \mathrm{B}$

$\mathrm{Q} / \mathrm{B}$

$\mathrm{U} / \mathrm{B}$

Trophic data

Landings

29. European conger

Biomass (meanmaximum)

$\mathrm{P} / \mathrm{B}$

$\mathrm{Q} / \mathrm{B}$

$\mathrm{U} / \mathrm{B}$

Trophic data

Landings

30. Poor cod

Biomass (meanmaximum)

$\mathrm{P} / \mathrm{B}$

$\mathrm{Q} / \mathrm{B}$

U/B

Trophic data

Landings
French Mediterranean bottom trawl surveys - IFREMER database MEDITS (1994-2009); Bertrand et al., 1998;

Campillo, 1992; Christensen et al., 2005;

Campillo, 1992; Palomares and Pauly, 1998; www.fishbase.org;

Christensen and Pauly, 1991;

Presciado et al., 2006;

FIS "Fisheries Information System"- IFREMER data on landings from auction sales Database (2002-2009); Demaneche et al., 2009 (landings 2007-2008);

French Mediterranean bottom trawl surveys - IFREMER database MEDITS (1994-2009); Bertrand et al., 1998;

Campillo, 1992; Christensen et al., 2005;

Campillo, 1992; Palomares and Pauly, 1998; www.fishbase.org;

Christensen and Pauly, 1991;

Bell and Harmelin, 1983; Cau and Manconi, 1984;

FIS "Fisheries Information System"- IFREMER data on landings from auction sales Database (2002-2009); Demaneche et al., 2009 (landings 2007-2008);

French Mediterranean bottom trawl surveys - IFREMER database MEDITS (1994-2009); Bertrand et al., 1998;

Farrugio et al., 1991; Christensen et al., 2005;

Campillo, 1992; Palomares and Pauly, 1998; www.fishbase.org;

Christensen and Pauly, 1991;

Santic et al., 2009;

FIS "Fisheries Information System"- IFREMER data on landings from auction sales Database (2002-2009); Demaneche et al., 2009 (landings 2007-2008);

31. Pelagic fish (feeding on fish)

Biomass (mean- $\quad$ French Mediterranean pelagic acoustic surveys - IFREMER database PELMED (1993-2009); maximum) Imbert et al., 2007; Banaru et al., 2010a;

P/B Campillo, 1992; Christensen et al., 2005;

Q/B Campillo, 1992; Palomares and Pauly, 1998; www.fishbase.org;

U/B Christensen and Pauly, 1991;

Trophic data Sever et al., 2006; Imbert et al., 2007;

Landings $\quad$ FIS "Fisheries Information System"- IFREMER data on landings from auction sales Database (2002-2009); Demaneche et al., 2009 (landings 2007-2008);

32. Bentho-demersal fish (feeding on fish)

Biomass (mean- $\quad$ French Mediterranean bottom trawl surveys - IFREMER database MEDITS (1994-2009); maximum) Bertrand et al., 1998;

$\mathrm{P} / \mathrm{B}$

Campillo, 1992; Christensen et al., 2005;

$\mathrm{Q} / \mathrm{B}$

Campillo, 1992; Palomares and Pauly, 1998; www.fishbase.org;

$\mathrm{U} / \mathrm{B}$

Christensen and Pauly, 1991;

Trophic data

Moreno-Amich, 1992; Olaso et al., 1998; Morte et al., 1999; Demirhan et al., 2005;

Banaru et al., 2009;

Landings

FIS "Fisheries Information System"- IFREMER data on landings from auction sales

Database (2002-2009); Demaneche et al., 2009 (landings 2007-2008);

33. Fish (feeding on benthic crustaceans)

Biomass (mean- $\quad$ French Mediterranean bottom trawl surveys - IFREMER database MEDITS (1994-2009); maximum)

$\mathrm{P} / \mathrm{B}$

Bertrand et al., 1998; Vaudo, 2002;

$\mathrm{Q} / \mathrm{B}$

Farrugio et al., 1991; Campillo, 1992; Christensen et al., 2005;

Campillo, 1992; Palomares and Pauly, 1998; www.fishbase.org;

$\mathrm{U} / \mathrm{B}$
Christensen and Pauly, 1991; 
Trophic data $\quad$ Mcpherson, 1978; Bell and Harmelin, 1983; Costa, 1988; Pisarevskaya and Aksenova, 1991; Morte et al., 1999; Bautista et al., 2008; Pasquaud et al., 2008; Fehri-Bedoui, 2009;

Landings

FIS "Fisheries Information System"- IFREMER data on landings from auction sales

34. Gilthead seabream

Database (2002-2009); Demaneche et al., 2009 (landings 2007-2008);

Biomass (mean- Vaudo, 2002;

maximum)

$\mathrm{P} / \mathrm{B}$

Campillo, 1992; Christensen et al., 2005;

$\mathrm{Q} / \mathrm{B}$

Campillo, 1992; Palomares and Pauly, 1998; www.fishbase.org;

$\mathrm{U} / \mathrm{B}$

Christensen and Pauly, 1991;

Trophic data

Rosecchi, 1987;

Landings

FIS "Fisheries Information System"- IFREMER data on landings from auction sales Database (2002-2009); Demaneche et al., 2009 (landings 2007-2008);

35. Fish (feeding on polychaetes, bivalves and gastropods)

Biomass (mean- $\quad$ French Mediterranean bottom trawl surveys - IFREMER database MEDITS (1994-2009);

maximum)

$\mathrm{P} / \mathrm{B}$

Bertrand et al., 1998; Vaudo, 2002;

$\mathrm{Q} / \mathrm{B}$

$\mathrm{U} / \mathrm{B}$

Farrugio et al., 1991; Campillo, 1992; Christensen et al., 2005;

Campillo, 1992; Palomares and Pauly, 1998; www.fishbase.org;

Christensen and Pauly, 1991;

Trophic data

Landings

Bell and Harmelin, 1983; Rosecchi, 1987; Rosecchi and Nouaze, 1987; Darnaude et al., 2004b; Kallianiotis et al., 2005;

36. Sea birds

FIS "Fisheries Information System"- IFREMER data on landings from auction sales

36. Sea birds

Database (2002-2009); Demaneche et al., 2009 (landings 2007-2008);

Biomass

Cadiou et al., 2004; Beaubrun, pers. comm.;

$\mathrm{P} / \mathrm{B}$

Cadiou et al., 2004; Beaubrun, pers. comm.;

$\mathrm{Q} / \mathrm{B}$

$\mathrm{U} / \mathrm{B}$

Cadiou et al., 2004; Beaubrun, pers. comm.;

Nilsson et al., 1976; Cadiou et al., 2004; Beaubrun, pers. comm.;

Christensen and Pauly, 1991;

Trophic data

37. Dolphins

(Odontocetes)

Biomass

Thezenas, 1993; Gonzales-Solis et al., 1997; Conéjéro, 1998; Cramm et al., 1998; Arcos, 1999; Louzao et al., 2009; Beaubrun, pers. comm.;

Beaubrun, 1995; Roussel et al., 2000; Ripoll et al., 2001;

$\mathrm{P} / \mathrm{B}$

$\mathrm{Q} / \mathrm{B}$

Roussel et al., 2000; Ripoll et al., 2001; Beaubrun, pers. comm.;

Ripoll et al., 2001; Beaubrun, pers. comm.;

Innes et al., 1987; Beaubrun, 1995; Trites et al., 1997;

$\mathrm{U} / \mathrm{B}$

Trophic data

Christensen and Pauly, 1991;

Astruc, 2005; Beaubrun, pers. comm.;

38. Whale

(Mysticetes)

Biomass

Beaubrun, 1995;

Beaubrun, 1995; Roussel et al., 2000;

$\mathrm{P} / \mathrm{B}$

Roussel et al., 2000; Beaubrun, pers. comm.;

$\mathrm{Q} / \mathrm{B}$

$\mathrm{U} / \mathrm{B}$

Innes et al., 1987; Beaubrun, 1995; Trites et al., 1997;

Christensen and Pauly, 1991;

Trophic data

Astruc, 2005; Ruchonnet et al., 2006; Beaubrun, pers. comm.;

39. Detritus

Biomass

estimated from primary production (Pauly et al., 1993; Dalsgaard and Pauly, 1997; Tanaka and Rassoulzadegan, 2002); detritus import from inputs of particulate organic matter by the Rhône river (Harmelin et al., 2010);

40. Discards

Biomass

SIH IFREMER data on landings from auction sales database (2002-2009); Demaneche et al., 2009 (landings 2007); IFREMER, 2009. 
Appendix 2. Cluster analysis using Ward method and mean distance between classes, representing the diet similarity between the 29 analysed fish species. Complete names of the species were indicated in Table 1 .

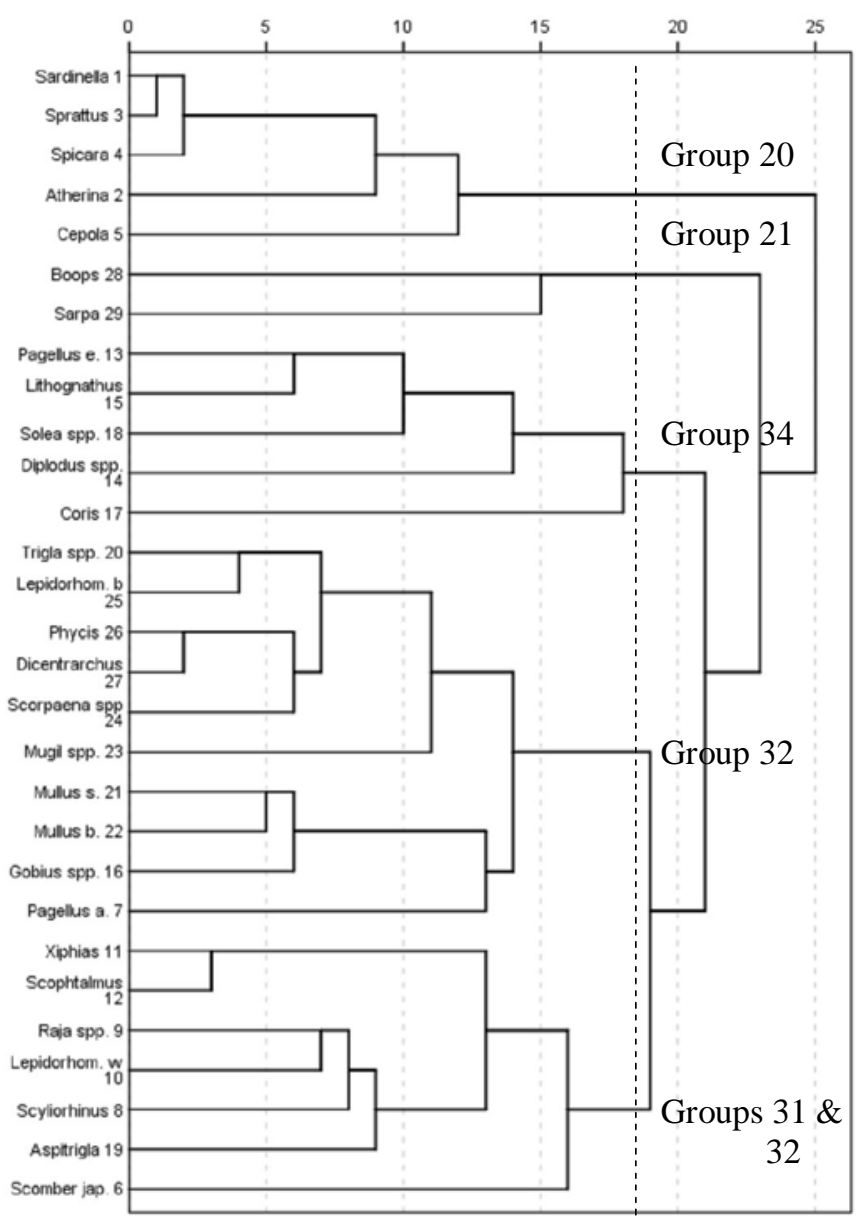


Appendix 3. Landings in the Gulf of Lions by French and Spanish fishing gear and by species (R3 report 20072008). G1 = Trawls 12-24 m, Purse seine < $12 \mathrm{~m}$; G2 = Trawls 24-40 m; G3 = Purse seine 12-24 m; G4 = Purse seine $>24 \mathrm{~m}$; G5 = Gillnet $<12 \mathrm{~m},<3 \mathrm{~nm}$; G6 = Gillnet $<12 \mathrm{~m}, 12-18 \mathrm{~m},>3 \mathrm{~nm}$; G7 = other small gears $<12 \mathrm{~m}$, $<3 \mathrm{~nm}$. Total R3 = sum of catches by gear from R3 report. Total $\mathrm{H}=$ total catches from Harmonie auction sales database (mean annual values over the period 2002-2009).

\begin{tabular}{|c|c|c|c|c|c|c|c|c|c|c|}
\hline & Functional group & G1 & $\mathrm{G} 2$ & G3 & G4 & G5 & G6 & G7 & $\begin{array}{l}\text { Total } \\
\text { R3 }\end{array}$ & $\begin{array}{l}\text { Total } \\
\mathrm{H}\end{array}$ \\
\hline 11 & Bivalves-Gastropods & 0.002 & 0.001 & & & 0.007 & & 0.094 & 0.104 & 0.016 \\
\hline 12 & Octopuses & 0.046 & 0.056 & & & 0.004 & & 0.010 & 0.116 & 0.078 \\
\hline 13 & Cuttlefish-squids & 0.011 & 0.013 & & & & & & 0.024 & 0.024 \\
\hline 14 & Benthic crustaceans & 0.001 & & & & & & 0.003 & 0.004 & 0.001 \\
\hline 15 & Lobsters & 0.001 & 0.002 & & & & & 0.002 & 0.005 & 0.004 \\
\hline 16 & Echinoderms & & & & & & & 0.011 & 0.011 & \\
\hline 18 & European pilchard & 0.132 & 0.554 & 0.196 & & 0.001 & & 0.001 & 0.884 & 0.481 \\
\hline 19 & European anchovy & 0.001 & 0.198 & 0.003 & & & & & 0.202 & 0.183 \\
\hline 20 & $\begin{array}{l}\text { Other planctonophagous } \\
\text { fish }\end{array}$ & 0.001 & 0.001 & & & & 0.003 & & 0.005 & 0.003 \\
\hline 21 & Fish (feeding on plants) & & & & & 0.009 & & 0.004 & 0.013 & 0.008 \\
\hline 22 & Atlantic mackerel & 0.025 & 0.092 & 0.004 & & & 0.001 & & 0.122 & 0.046 \\
\hline 23 & $\begin{array}{l}\text { Mediterranean horse } \\
\text { mackerel }\end{array}$ & 0.005 & 0.004 & & & & & & 0.009 & 0.011 \\
\hline 25 & Atlantic bluefin tuna & & & & 0.043 & & 0.021 & & 0.064 & 0.064 \\
\hline 26 & Hake age & 0.029 & 0.063 & & & 0.003 & 0.010 & 0.006 & 0.111 & 0.111 \\
\hline 27 & Atlantic horse mackerel & 0.022 & 0.048 & 0.001 & & 0.005 & 0.002 & & 0.078 & 0.045 \\
\hline 28 & Anglerfish & 0.004 & 0.017 & & & 0.002 & 0.001 & & 0.024 & 0.020 \\
\hline 29 & European conger & 0.012 & 0.01 & & & 0.004 & & 0.017 & 0.043 & 0.015 \\
\hline 30 & Poor cod & 0.015 & 0.046 & & & & & & 0.061 & 0.032 \\
\hline 31 & $\begin{array}{l}\text { Pelagic fish } \\
\text { (feeding on fish) }\end{array}$ & & & & & 0.001 & 0.001 & & 0.002 & 0.000 \\
\hline 32 & $\begin{array}{l}\text { Bentho-pelagic fish } \\
\text { (feeding on fish) }\end{array}$ & 0.014 & 0.015 & & & 0.001 & & & 0.030 & 0.026 \\
\hline 33 & $\begin{array}{l}\text { Fish (feeding on benthic } \\
\text { crustaceans) }\end{array}$ & 0.030 & 0.028 & 0.003 & & 0.036 & 0.006 & 0.014 & 0.117 & 0.068 \\
\hline 34 & Gilthead seabream & 0.009 & 0.007 & & & 0.020 & 0.003 & 0.005 & 0.044 & 0.017 \\
\hline \multirow[t]{2}{*}{35} & $\begin{array}{l}\text { Fish (feeding on } \\
\text { polychaetes) }\end{array}$ & 0.013 & 0.013 & & & 0.020 & 0.007 & 0.005 & 0.058 & 0.021 \\
\hline & Sum & 0.373 & 1.168 & 0.207 & 0.043 & 0.113 & 0.055 & 0.172 & 2.131 & 1.274 \\
\hline
\end{tabular}


Appendix 4. Differences between the two landings data sources (report R3 and Harmonie auction sales) in 2007.

\begin{tabular}{llccc}
\hline & Functional group & \multicolumn{3}{c}{ Landings (tons km } \\
& & & \\
& $\mathrm{R} 3(2007)$ & $\mathrm{H}(2007)$ & $\mathrm{R} 3 / \mathrm{H}$ \\
\hline 11 & Bivalves-Gastropods & 0.104 & - & \\
12 & Octopuses & 0.108 & 0.081 & 1.3 \\
13 & Cuttlefish-squids & 0.022 & - & \\
14 & Benthic crustaceans & 0.004 & - & \\
15 & Lobsters & 0.002 & - & \\
16 & Echinoderms & 0.011 & - & \\
18 & European pilchard & 0.729 & 0.654 & 1.1 \\
19 & European anchovy & 0.201 & 0.203 & 1.0 \\
20 & Other planctonophagous fish & 0.005 & - & \\
21 & Fish (feeding on plants) & 0.013 & 0.001 & 10.8 \\
22 & Atlantic mackerel & 0.121 & 0.081 & 1.5 \\
23 & Mediterranean horse mackerel & 0.002 & - & \\
26 & Hake & 0.101 & 0.083 & 1.2 \\
27 & Atlantic horse mackerel & 0.046 & 0.030 & 1.5 \\
28 & Anglerfish & 0.020 & 0.011 & 1.9 \\
29 & European conger & 0.041 & 0.015 & 2.7 \\
30 & Poor cod & 0.059 & 0.036 & 1.6 \\
31 & Pelagic fish (feeding on fish) & 0.002 & - & \\
32 & Bentho-demersal fish (feeding on fish) & 0.030 & 0.012 & 2.5 \\
33 & Fish (feeding on benthic crustaceans) & 0.109 & 0.037 & 2.9 \\
34 & Gilthead seabream & 0.044 & 0.012 & 3.7 \\
35 & Fish (feeding on polychaetes) & 0.058 & 0.021 & 2.8 \\
\hline
\end{tabular}

